\title{
STRUCTURAL AND FUNCTIONAL RESPONSES OF A SUBTROPICAL FOREST TO 10 YEARS OF HURRICANES AND DROUGHTS
}

\author{
Karen H. Beard, ${ }^{1,6}$ Kristina A. Vogt, ${ }^{2}$ Daniel J. Vogt,${ }^{2}$ Frederick N. Scatena, ${ }^{3}$ Alan P. Covich, ${ }^{4}$ \\ Ragnhildur Sigurdardottir, ${ }^{5}$ Thomas G. Siccama, ${ }^{5}$ And Todd A. Crowl ${ }^{1}$ \\ ${ }^{1}$ Forest, Range and Wildife Sciences and Ecology Center, Utah State University, Logan, Utah 84322 USA \\ ${ }^{2}$ College of Forest Resources, University of Washington, Seattle, Washington 98195 USA \\ ${ }^{3}$ Department of Earth and Environmental Science, University of Pennsylvania, Philadelphia, Pennsylvania 19104 USA \\ ${ }^{4}$ Institute of Ecology, University of Georgia, Athens, Georgia 30602 USA \\ ${ }^{5}$ School of Forestry and Environmental Studies, Yale University, New Haven, Connecticut 06511 USA
}

\begin{abstract}
Little is known about ecosystem-level responses to multiple, climatic disturbance events. In the subtropical forests of Puerto Rico, the major natural disturbances are hurricanes and droughts. We tested the ecosystem-level effects of these disturbances in sites with different land use histories. From 1989 to 1992, data were collected to determine the effects of Hurricane Hugo and two droughts on litterfall inputs, fine-root biomass, and decomposition rates in three topographic locations (stream, riparian, upslope) within two watersheds. From 1994 to 1998 , we added a third watershed and an experiment in which coarse-wood levels were manipulated to simulate hurricane inputs. Data were collected on tree and palm growth rates, litterfall inputs, fine-root biomass, and decomposition rates. From 1994 to 1998, four hurricanes and three droughts were recorded.

Measured parameters had unique responses and recovery rates to hurricanes and droughts. Litterfall inputs returned to long-term mean rates within one month following droughts and small-to-moderate hurricanes but required five years to recover after an intense hurricane. In contrast, fine-root biomass recovered seven months after an intense hurricane but failed to recover after five years following a severe drought. Despite the dramatic effects of these weather events on some ecosystem parameters, we found that aboveground measures of tree and palm growth were more affected by preexisting site conditions (e.g., nitrogen availability due to past land use activities) than hurricanes or droughts. The addition of coarse woody debris increased tree and palm growth, fine-root biomass, and litter production; however, in the case of tree and palm growth, this effect was least measurable in the sites with the highest productivity. We found that decomposition rates were more controlled by litter quality than weather conditions. In conclusion, we found that certain ecosystem structures (e.g., canopy structure and fine-root biomass) generally recovered more slowly from disturbance events than certain ecosystem processes (e.g., plant growth rates, decomposition rates). We also found that past land use activities and disturbance legacies were important in determining the responses and recovery rates of the ecosystem to disturbance.
\end{abstract}

Key words: decomposition; disturbance; drought; fine roots; hurricane; land use legacy; litterfall; Luquillo Experimental Forest; productivity; Puerto Rico; recovery; tropics.

\section{INTRODUCTION}

Natural disturbances are major driving forces in the structure and function of the subtropical forests in Puerto Rico. Hurricanes and severe tropical storms pass sufficiently close to Puerto Rico to influence ecosystem properties every 2-5 years (Vogel 1994). Droughts, which can occur after hurricanes as well as in nonhurricane years, are also important ecosystem drivers, but they are generally less well understood (but see Covich et al. [2003]). Impacts of natural disturbances on the structure and functioning of an ecosystem are known to depend on their type and intensity, the area

Manuscript received 13 July 2004; revised 23 December 2004; accepted 4 January 2005. Corresponding Editor: D. P. C. Peters.

6E-mail: karen.beard@usu.edu affected, and the degree to which structure and function has recovered between disturbances (Scatena 1995). However, few studies have determined the relative importance of different natural disturbance events in a subtropical forest over an extended period of time. In addition, while most research has been conducted on either a severe hurricane or prolonged drought, it is not clear whether less severe storms and droughts have important cumulative effects on ecosystems.

Depending on their intensity, hurricane winds and rains are known to have both short- and long-term effects on forest structure and function in Puerto Rico. Hurricanes cause obvious and immediate impacts on standing vegetation by causing sudden and massive defoliation, delimbing, and uprooting (Lugo and Scatena 1996). However, some effects take more time to 
manifest themselves. For example, tree mortality can be delayed for years (Frangi 1998), and because plant species respond differently to hurricanes, long-term changes in the successional direction of the forest can occur (Zimmerman et al. 1994). Other hurricane effects, such as those that influence soil development (Scatena and Larsen 1991) and nutrient cycling (Sanford et al. 1991), can occur over time scales involving tree generations.

Research on natural disturbances in Puerto Rico has largely focused on hurricanes, landslides, and tree falls. Droughts have received far less attention because they are often not thought to be ecosystem drivers in subtropical forests (Covich et al. 2003). However, prolonged droughts have been recorded somewhere on the island of Puerto Rico every 10 years, and 15 consecutive days without rainfall occur about once every 15 years in the lower Luquillo Mountains (Scatena 1995). Research conducted in the subtropics has shown that droughts cause some of the same effects as those found in temperate areas (Vogt et al. 1996). Most drought studies in the Luquillo Experimental Forest (LEF), Puerto Rico, have examined effects on aquatic habitat and community dynamics (Covich et al. 2003) or terrestrial fauna (Schowalter and Ganio 1999).

Recovery time, the period required for a feature or process to return to its pre-disturbance form or rate following disturbance (DeAngelis 1980), is determined by the magnitude of the disturbance and characteristics of the ecosystem. For example, biomass recovery required about five years in the Bisley Experimental Watershed, Puerto Rico, when $50 \%$ of the living vegetative biomass was transferred to the forest floor (Scatena et al. 1996). Presumably, it would be shorter or longer depending on the level of damage. If recovery periods are shorter than the frequency of disturbance events, then the ecosystem is thought to be resilient and able to maintain functioning following disturbances (Vogt et al. 1997). However, research conducted on recovery times of ecosystem indicators in Puerto Rico has largely focused on single disturbance events (Scatena et al. 1996, Silver et al. 1996, Walker et al. 1996). Therefore, several questions remain: How resistant and resilient are ecosystem parameters to multiple, natural disturbance events? How do ecosystem parameters respond to different natural disturbances? What mechanisms might have evolved to allow forest structure and function to recover?

The manifestation of disturbance events and the rate and nature of recovery may greatly depend on land use legacies in existence at the site prior to disturbance (Chazdon 2003). Land use legacies have been found to influence ecosystem structure and function for decades, centuries, or even longer after those activities have ceased (Foster et al. 2003). In the LEF, even though some land practices stopped 40-60 years ago, they have left a legacy on the landscape that is greater than the effects of hurricanes, landslides, and treefalls
(Thompson et al. 2002, Chinea and Helmer 2003, Zimmerman and Covich 2003). The ability of legacies to change the response of ecosystem parameters to disturbance will depend upon the type and imprint of the legacy on the ecosystem as well as the degree to which the affected parameters control site productivity.

Past disturbance events also create a legacy on the landscape that may affect the response of an ecosystem to future disturbances (Foster et al. 2003). For example, one consequence of hurricanes is the large pulse of aboveground biomass converted to necromass. Many studies on the importance of the conversion of necromass to available nutrients following disturbance have focused on fine litter (Lodge et al. 1991, Ostertag et al. 2003). However, a significant amount (85\%) of the litter added to the forest floor during a hurricane can be coarse woody debris (CWD) (Scatena et al. 1993). Because CWD often decomposes over several decades, it can have medium- to long-term impacts on nutrient availability and conservation (Harmon et al. 1995).

The main objectives of our study were to determine the following in the LEF, Puerto Rico: (1) whether hurricanes or droughts have the greatest influence on different ecosystem indicators; (2) which ecosystem indicators are resistant and resilient to these events; (3) when ecosystem indicators return to pre-disturbance levels; and (4) how legacies of past land use and disturbance influence ecosystem response to disturbance.

\section{Methods \\ Experimental design}

Study sites.-Research was conducted in the LEF in the northeastern region of Puerto Rico $\left(18^{\circ} 18^{\prime} \mathrm{N}\right.$, $\left.65^{\circ} 47^{\prime} \mathrm{W}\right)$. The study forest is classified as subtropical wet (Ewel and Whitmore 1973), and soils are classified as clay and silty clay loam Ultisols in the Los Guineos soil series (Boccheciamp 1977). Peak precipitation occurs between May and November, with mean inputs of $\sim 400 \mathrm{~mm} / \mathrm{mo}$, and drier periods occur between January and April when precipitation averages $200-250 \mathrm{~mm} /$ mo (Garcia-Martino et al. 1996). Mean monthly air temperatures are fairly constant throughout the year and average between $21^{\circ}$ and $24^{\circ} \mathrm{C}$ (Garcia-Martino et al. 1996). All of the study sites were located in mature secondary tabonuco (Dacryodes excelsa Vahl.) forest. The forest is also dominated by Prestoea montana (Graham), Manilkara bidentata (A. DC), Sloanea berteriana (Choisy), and Cecropia schreberiana (Miq.).

There were two phases of this research: Phase 1 from 1989-1992 and Phase 2 from 1994-1998. Permanent plots used for both phases were established in two separate catchments: La Prieta Watershed in El Verde (EV) Experimental Forest and the Bisley Experimental Watershed area, at the number 3 (B3) gauged watershed. Another catchment was added for Phase 2 of the research in the Bisley Experimental Watershed area, the 
number 5 (B5) watershed (see map in Scatena and Larsen [1991]). The plots in EV were along the Quebrada La Prieta, a perennial second-order tributary that flows into Quebrada Sonadora. The plots in Bisley were located along study streams, B3 and B5, which are firstorder tributaries to the Rio Mameyes. All streams are perennial, 3-5 $\mathrm{m}$ wide, and have a steep gradient of boulder- and bedrock-lined channels. All stream channels have woody vegetation along the banks with nearly complete, but variable, canopy cover.

Vegetation, soil, and ecosystem processes are closely linked with topographic location in this forest (Wadsworth 1951, Scatena and Lugo 1995). Therefore, within each catchment, three topographic areas were designated: stream pools, riparian zones, and upslope areas. Stream pools were areas bordering the plots with at least $20 \mathrm{~cm}$ maximum depth during base flow and no surface turbulence. The riparian zone was the area adjacent to a stream that floods periodically and receives and accumulates upland runoff. Upslope areas were located adjacent to the riparian zone and not on a ridge. None of the plots flooded during the study. Elevation, slope, and aspect by catchment and topographic location are summarized in Table 1.

Coarse-wood manipulations.-We conducted a wood manipulation experiment to simulate the effects of adding coarse wood at a minimum rate equivalent to Hurricane Hugo (estimated to be $120 \mathrm{Mg} / \mathrm{ha}$; Scatena et al. 1993). During Phase 1 , one $30 \times 30 \mathrm{~m}$ plot containing each of the three topographic locations was established in each catchment (EV and B3). These plots were used to study ecosystem responses to natural disturbance events during both phases. During Phase 2, these $30 \times 30 \mathrm{~m}$ plots were converted to control plots and two additional $30 \times 30 \mathrm{~m}$ plots were established in each catchment parallel to the stream and downstream of the "control" plot. These plots became treatments: a coarse "wood-addition" plot and a coarse "wood-removal" plot. In each catchment, the upstream plot was the control plot, the next plot downstream was the wood-addition plot, and the plot farthest downstream was the wood-removal plot. Plots were separated by $70 \mathrm{~m}$ such that no drainage was possible between plots during major storm events. The same plot design was used to establish plots at B5 for a complete $(3 \times 3)$ block design.

In January 1995, the amount of CWD $(\operatorname{logs} \geq 10$ $\mathrm{cm}$ diameter) was determined on each plot prior to implementation of the treatments. This procedure allowed us to determine how much CWD was present in the control plots, how much CWD would be removed from the wood-removal plots, and how much existing CWD would be added to in the wood-addition plot. All CWD was removed from the wood-removal plots so that there was no effect of CWD on that treatment; new coarse wood that fell into these plots was removed every six months for two years after plot establishment. Each wood-removal plot had different amounts of de- caying wood present. The total mass of wood removed varied by catchment: EV, $4.6 \mathrm{Mg} / \mathrm{ha}$; B3, $40.9 \mathrm{Mg} / \mathrm{ha}$; and $\mathrm{B} 5,55.0 \mathrm{Mg} / \mathrm{ha}$. The three plots in $\mathrm{EV}$ had less decaying wood on the forest floor (4.6-8.0 Mg/ha) than the plots in B3 or B5 (40.9-63.9 Mg/ha).

At each catchment, the number of live trees (mainly $D$. excelsa with some $M$. bidentata) needed to mimic hurricane wood inputs was estimated on an area basis. At least four large trees were cut outside of each woodaddition plot; tree diameters at breast height (dbh) ranged from 21 to $35 \mathrm{~cm}$ for D. excelsa and from 35 to $45 \mathrm{~cm}$ for $M$. bidentata. Each tree was further cut into $100 \mathrm{~cm}$ long wood pieces. To estimate the mass of wood added, each wood piece had its diameter and length measured and cross sections cut from both ends. The logs and cross sections were weighed to obtain a wet mass; cross sections were dried and weighed in the laboratory to develop a wet-to-dry mass conversion factor.

This conversion factor was used to calculate the amount of dry wood added to each wood-addition plot: between 270 and 360 wood pieces or $150-300 \mathrm{Mg} / \mathrm{ha}$. A third of the wood for each plot was placed in the riparian zone ca. $5 \mathrm{~m}$ up from the stream edge and extended upslope $\sim 4-6 \mathrm{~m}$. Another third of the wood for each plot was added to the upslope area starting 5 $\mathrm{m}$ downslope from the uppermost plot boundary and extending downslope $\sim 4-6 \mathrm{~m}$. The last third was added to the stream pools immediately adjacent to each woodaddition plot where the wood was secured to nearby boulders or trees.

Land use history.--Recent research has determined how past land use has influenced forest composition in the study catchments (Garcia-Montiel and Scatena 1994, Thomlinson et al. 1996, Thompson et al. 2002). As suggested by 1936 aerial photos of EV (Thompson et al. 2002), these plots were historically occupied by homes. As evidenced by the low relative importance of tabonuco and manilkara (Table 2), the two Bisley catchments had single-tree harvesting for timber and charcoal (Scatena 1989). The B3 site was also used for subsistence farming, and B5 is thought to have been a coffee plantation because of the high abundance of $\mathrm{N}_{2^{-}}$ fixing shade species, Inga vera, I. laurina, and Guarea guidonia, in the upslope areas (Garcia-Montiel and Scatena 1994). The B5 site appears enriched in soil N as a result (Table 1) and has a high abundance of nettle (Urera baccifera), a species associated with high soil $\mathrm{N}$ concentrations.

Disturbances.-This study was conducted over a 10year period of high weather instability in which hurricanes and droughts occurred biannually. Using category 1 (Cat 1 , least intense) or above on the SaffirSimpson scale as the definition of a hurricane event, six hurricanes occurred during this study. The intensity of these events differed, but can be described by their category numbers and proximities to the study forest. Hurricane Hugo (1989, Cat 4) was the most intense 
TABLE 1. Site and soil characteristics by catchment and topographic location for the plots in El Verde (EV) and Bisley Experimental Watersheds number 3 (B3) and number 5 (B5) in Luquillo Experimental Forest, Puerto Rico.

\begin{tabular}{|c|c|c|c|c|c|c|}
\hline \multirow[b]{2}{*}{ Site } & \multirow[b]{2}{*}{ Location } & \multirow[b]{2}{*}{ Aspect } & \multirow[b]{2}{*}{ Slope $\left({ }^{\circ}\right)$} & \multirow{2}{*}{$\begin{array}{l}\text { Elevation } \\
\text { (m a.s.1.) }\end{array}$} & \multicolumn{2}{|c|}{ Soil moisture $(\%) \dagger \neq$} \\
\hline & & & & & Mean (SE) & Range \\
\hline EV & $\begin{array}{l}\text { riparian } \\
\text { upslope }\end{array}$ & $\begin{array}{l}\text { W-NW } \\
\mathrm{N}\end{array}$ & $\begin{array}{l}11(3) \\
17(3)\end{array}$ & $\begin{array}{l}350-430 \\
350-430\end{array}$ & $\begin{array}{l}79.7^{\mathrm{a}}(3.9) \\
77.3^{\mathrm{a}}(2.6)\end{array}$ & $\begin{array}{l}56.4-122.3 \\
60.0-101.9\end{array}$ \\
\hline B3 & $\begin{array}{l}\text { riparian } \\
\text { upslope }\end{array}$ & $\begin{array}{l}\text { E-NE } \\
\text { E-NE }\end{array}$ & $\begin{array}{l}21(5) \\
25(5)\end{array}$ & $\begin{array}{l}230-300 \\
230-300\end{array}$ & $\begin{array}{l}81.8^{\mathrm{a}}(1.6) \\
83.3^{\mathrm{a}}(3.26)\end{array}$ & $\begin{array}{l}67.9-99.2 \\
62.9-124.8\end{array}$ \\
\hline B5 & $\begin{array}{l}\text { riparian } \\
\text { upslope }\end{array}$ & $\begin{array}{l}\text { N-NW } \\
\text { N-NW }\end{array}$ & $\begin{array}{l}15(4) \\
18(4)\end{array}$ & $\begin{array}{l}250-310 \\
250-310\end{array}$ & $\begin{array}{l}98.6^{\mathrm{b}}(4.98) \\
71.2^{\mathrm{a}}(3.09)\end{array}$ & $\begin{array}{l}65.0-159.2 \\
47.7-144.5\end{array}$ \\
\hline
\end{tabular}

Notes: Mean values are presented (with SE in parentheses). Sample sizes: soil moisture, $n=26$; soil C and $\mathrm{N}, n=6$; $\mathrm{NH}_{4}{ }^{-}-\mathrm{N}$ and $\mathrm{NO}_{3}^{-}-\mathrm{N}, n=68$ riparian, $n=64$ upslope. Soil cores were taken to a depth of $30 \mathrm{~cm}$.

$\dagger$ Mean values followed by the same lowercase letters are not significantly different in comparisons across site and topographic location (Tukey's comparisons of means, $P<0.05$ ).

\$ Soil moisture by dry mass and $\mathrm{NH}_{4}{ }^{-}-\mathrm{N}$ and $\mathrm{NO}_{3}{ }^{-}-\mathrm{N}$ concentrations were determined monthly from August 1994 to May 1999, and total percentages of soil carbon (C) and nitrogen (N) were determined in February 1998.

hurricane to pass over Puerto Rico during the study period. Hurricanes Luis (1995, Cat 4) and Marilyn (1995, Cat 2) occurred within two weeks of each other and are considered together because most sampling occurred at monthly intervals. Hurricanes Bertha (1996, Cat 1) and Hortense (1996, Cat 1) occurred within two months of each other and are considered separate events. Although other hurricanes were placed in higher categories, Hurricane Georges (1998, Cat 2) was the second-most intense hurricane to hit the study forest because of the proximity of its pathway.

The definition of a drought is more difficult than that of a hurricane because it differs between ecosystem types (Humphries and Baldwin 2003). We used the number of days with low precipitation as our definition because our study focused on vegetation responses to drought. A drought occurred if rainfall was below 150 $\mathrm{mm} / \mathrm{mo}$ for at least two consecutive months based on long-term data showing that precipitation averages 200-250 mm/mo between January and April and 400 $\mathrm{mm} / \mathrm{mo}$ between May and November (Garcia-Martino et al. 1996). There were five droughts during the study period: (1) post-Hurricane Hugo (October-December 1989), (2) 1991 (January-April), (3) 1994 (AprilJune), (4) 1996 (February-March), and (5) 1997 (March-April). The most prolonged drought occurred in 1991, but the most severe drought occurred in 1994 (Larsen 2000).

\section{Measurements}

Tree growth.-In January 1995, all trees on each plot were tagged and identified, and their diameters at breast height were measured and recorded. These data were used to determine relative importance values based on relative tree basal areas and relative tree densities. The 18 dominant trees in each plot, based on species composition and size, had dendrometer bands attached at breast height. Starting in January 1996, changes in diameter were recorded monthly for 12 consecutive months, and for the next 18 months, changes were determined every 3-4 months. Allometric relationships between dbh and biomass were used to determine tree biomass (Table 2; Scatena et al. 1993). Trees without dendrometer bands were used to determine mortality rates $3,4,5$, and 8 years after the initiation of the experiment.

Palm growth.-Biomass and productivity of palms cannot be determined using dbh measurements. In May 1995, 10 randomly selected palms $<2 \mathrm{~m}$ in height per plot in each catchment (EV, B3, and B5) were individually tagged (cohort 1 ), and the number of fronds was recorded. In January 1997, the first cohort of fronds was monitored for growth, mortality, and production, and all new fronds produced were tagged and labeled as cohort 2. Both cohorts were monitored in January 1998, June 1999, and January 2000.

Litterfall collection.-Litterfall was collected from EV and B3 from August 1989 to April 1992 and from all three catchments from June 1994 to January 1998. Litterfall was collected every two weeks during phase 1 (see methods in Vogt et al. [1996]) and monthly during phase 2 . To collect litterfall, we placed five replicate open-top plastic baskets $\left(1440 \mathrm{~cm}^{2}\right.$ collection surface area each) lined with fiberglass in the riparian zone and in the upslope areas. Five litterfall collectors made of inert plastic mesh material $\left(30000-\mathrm{cm}^{2}\right.$ collection surface area, $61 \mathrm{~cm}$ deep) were placed above stream pools.

Litterfall sampling methods differed from the above only following Hurricane Hugo. Inputs of fine $(<1 \mathrm{~cm}$ diameter) aboveground litter transfers were measured by sampling the forest floor three weeks after the hurricane hit the island. Litter inputs added as a result of the hurricane were distinguishable from the pre-Hugo forest floor. At each topographic location (i.e., riparian and upslope), fine-litter inputs were collected in ten 50 $\times 50 \mathrm{~cm}$ subplots to determine leaf and fine-wood inputs due to the hurricane. Stream litterfall samples following Hugo were assumed to be equivalent to litterfall in the riparian zone because there were restrictions placed on sampling at that time.

Litter samples were oven-dried at $70^{\circ} \mathrm{C}$, and dry masses (in grams per square meter) were determined by 
TABle 1. Extended.

\begin{tabular}{|c|c|c|c|c|c|}
\hline \multirow{2}{*}{$\begin{array}{l}\text { Total soil C } \\
(\%)\end{array}$} & \multirow{2}{*}{$\begin{array}{c}\text { Total soil } \mathrm{N} \\
(\%)\end{array}$} & \multicolumn{2}{|c|}{$\mathrm{NH}_{4}{ }^{+}-\mathrm{N}(\mathrm{mg} / \mathrm{kg})$} & \multicolumn{2}{|c|}{$\mathrm{NO}_{3}{ }^{-}-\mathrm{N}(\mathrm{mg} / \mathrm{kg})$} \\
\hline & & Mean (SE) & Range & Mean (SE) & Range \\
\hline $3.8^{\mathrm{ab}}(1.3)$ & $0.37^{\mathrm{ab}}(0.09)$ & $6.8^{\mathrm{a}}(0.45)$ & $2.5-13.7$ & $0.6^{\mathrm{a}}(0.08)$ & $0.01-3.0$ \\
\hline $3.0^{\mathrm{a}}(0.6)$ & $0.31^{\mathrm{a}}(0.04)$ & $7.8^{\mathrm{a}}(0.48)$ & $3.2-17.0$ & $0.7^{\mathrm{a}}(0.06)$ & $0.2-1.7$ \\
\hline $3.2^{\mathrm{a}}(0.7)$ & $0.29^{\mathrm{a}}(0.03)$ & $4.4^{\mathrm{a}}(0.38)$ & $0.9-10.3$ & $1.7^{\mathrm{a}}(0.13)$ & $0.7-3.4$ \\
\hline $3.1^{\mathrm{a}}(0.5)$ & $0.29^{\mathrm{a}}(0.05)$ & $6.9^{\mathrm{a}}(0.53)$ & $1.3-15.0$ & $1.5^{\mathrm{a}}(0.11)$ & $0.2-3.7$ \\
\hline $4.4^{\mathrm{b}}(1.3)$ & $0.42^{\mathrm{b}}(0.09)$ & $6.8^{\mathrm{a}}(0.58)$ & $0.2-20.4$ & $6.7^{\mathrm{b}}(0.49)$ & $3.9-13.6$ \\
\hline $3.0^{\mathrm{a}}(0.3)$ & $0.32^{\mathrm{a}}(0.03)$ & $4.9^{\mathrm{a}}(0.49)$ & $0.2-16.5$ & $6.5^{\mathrm{b}}(0.43)$ & $3.0-14.9$ \\
\hline
\end{tabular}

category: leaves, wood $<1 \mathrm{~cm}$ in diameter, palm rachis, other (miscellaneous reproductive parts, flowers, fruits, etc.), and the total. Litterfall was converted to a daily basis to account for differences in sampling intervals. Litterfall values may be underestimates due to decomposition between collection periods.

Fine-root turnover.-Fine-root sampling procedures and experimental designs are described in Vogt et al. (1995). Fine roots $(<2 \mathrm{~mm}$ in diameter, oven dried at $70^{\circ} \mathrm{C}$ ) were determined from root cores taken to a depth of $30 \mathrm{~cm}$. During Phase 1, 10 replicate cores were collected in the riparian zone and 10 in the upslope areas at EV and B3. From July 1989 to February 1990, root cores were sorted into live and dead categories. From March 1990 to May 1991, root cores were sorted for total (live + dead) fine roots. From July 1994 to July 1997, root cores were collected from all three catchments and sorted into live and dead categories; three replicate cores were collected in the riparian zone and three in the upslope areas per plot.

Leaf and root decay.-The decomposition rate of $D$. excelsa and P. montana leaf and fine-root tissues were determined in streams, riparian zones, and upslope areas at both EV and B3. Sampling design and procedures used to process tissues (plus decomposition data for leaves and fine roots in the terrestrial areas) are documented in Bloomfield (1993). Litterbags were constructed of fiberglass-coated nylon with $1.5-\mathrm{mm}$ mesh openings, and 10 replicate bags were produced per tissue type for each location and collection date. Decomposition rates were determined starting three months before Hugo (June 1989) and data were obtained after 3, 6, 9, and 12 months.

Small wood decay.-At both EV and B3, a study was established two months after Hugo to document small wood decay rates in the riparian zones and upslope areas (streams were subject to ongoing research and unavailable for sampling). Design and procedures are described in Vogt et al. (1996). Live D. excelsa trees blown down during Hugo were used for this study. Wood was cut into $50 \mathrm{~cm}$ long sections of two diametersize classes: $1-3 \mathrm{~cm}$ and 3-6 $\mathrm{cm}$. Decay rates were determined using mass loss measurements after 6 and 12 months from 10 replicate pieces for each size class and location.
Coarse-wood decay.-During Phase 2, coarse-wood decomposition rates were determined using changes in density of material added to the wood-addition plot at each catchment. Coarse-wood decomposition rates were determined in 1996, 1997, and 1998 from changes in wood density from the original green mass (Berni et al. 1979). These pieces were also used to measure changes in wood chemistry for D. excelsa and $M$. bidentata during decomposition. When collecting wood samples, 12 wood pieces were collected from the stream pools, six from the riparian zone, and six from the upslope areas. Because different tree species were originally used in the wood-addition plots and their placement by topographic location varied, replication for decomposition rates and coarse-wood chemistry by species and location varied by catchment and sampling time.

Cross-sections cut from each wood piece in the field were cut into wedges (15-100 g wet) for further laboratory analyses. A subsample of each wedge section was used to determine moisture content, density, $\mathrm{C}$ and $\mathrm{N}$ chemistry, and lignin. Wood subsamples were analyzed for total $\mathrm{C}$ and $\mathrm{N}$ by dry combustion using the CHN elemental analyzer (LECO CHN-600; LECO, St. Joseph, Michigan, USA) and for secondary chemicals, in particular percentage of lignin, using standard cellwall fractionation and fiber analyses (Goering and van Soest 1970, Anderson and Ingram 1989).

\section{Data analysis}

We considered the effects of catchment (EV, B3, or B5), topographic location (stream, riparian, or upslope), wood treatment (wood addition, wood removal, or control), and their interactions on ecosystem parameters through time. Sampling periods were defined by the disturbance events: Hurricanes Hugo, Luis and Marilyn, Bertha, Hortense, and Georges, and droughts post-Hugo, 1991, 1994, 1996, and 1997. Catchment, topographic location, and/or wood treatment were modeled as a multiway factorial in a completely randomized ANOVA design.

Analyses were conducted for litterfall and fine-root parameters on data from control plots in catchments EV and B3 during both phases to analyze disturbance effects over the entire sampling period. Analyses of 
TABle 2. Phytological data by treatment and catchment (El Verde, Bisley 3, and Bisley 5) at the Luquillo Experimental Forest, Puerto Rico, at the initiation of the coarse woody debris experiment.

\begin{tabular}{|c|c|c|c|c|c|c|c|}
\hline \multirow[b]{2}{*}{$\begin{array}{l}\text { Treatment } \\
\text { and site } \dagger\end{array}$} & \multicolumn{5}{|c|}{ Trees } & \multicolumn{2}{|c|}{ Palms } \\
\hline & $\begin{array}{c}\text { Stem } \\
\text { density } \\
\text { (no. stems/ha) }\end{array}$ & $\begin{array}{c}\text { Basal } \\
\text { area } \\
\left(\mathrm{m}^{2} / \mathrm{ha}\right)\end{array}$ & $\begin{array}{l}\text { Aboveground } \\
\text { biomass } \\
(\mathrm{Mg} / \mathrm{ha})\end{array}$ & $\begin{array}{l}\text { D. excelsa } \\
\text { relative } \\
\text { importance }\end{array}$ & $\begin{array}{l}\text { M. bidentata } \\
\text { relative } \\
\text { importance }\end{array}$ & $\begin{array}{c}\text { Understory } \\
\text { density } \\
\text { (no. stems/ha) } \$\end{array}$ & $\begin{array}{c}\text { Understory } \\
\text { aboveground } \\
\text { biomass }(\mathrm{Mg} / \mathrm{ha})\end{array}$ \\
\hline \multicolumn{8}{|l|}{ El Verde } \\
\hline W- & 1800 & 35.8 & 171.5 & 37.7 & 11.6 & 200 & 10.6 \\
\hline $\mathrm{C}$ & 1467 & 40.2 & 176.4 & 28.7 & 11.9 & 311 & 16.5 \\
\hline $\mathrm{W}+$ & 1067 & 38.3 & 237.9 & 2.5 & 1.8 & 278 & 12.6 \\
\hline \multicolumn{8}{|l|}{ Bisley 3} \\
\hline W- & 1444 & 23.7 & 110.3 & 0.5 & 0 & 222 & 11.8 \\
\hline $\mathrm{C}$ & 1133 & 31.0 & 186.6 & 5 & 9.1 & 89 & 4.0 \\
\hline $\mathrm{W}+$ & 1055 & 28.2 & 159.4 & 11.2 & 0 & 89 & 4.7 \\
\hline \multicolumn{8}{|l|}{ Bisley 5} \\
\hline $\mathrm{W}-$ & 2155 & 38.5 & 209.9 & 10.9 & 1.6 & 78 & 2.9 \\
\hline $\mathrm{C}$ & 1666 & 34.6 & 200.0 & 4.4 & 0 & 133 & 4.0 \\
\hline $\mathrm{W}+$ & 2644 & 48.2 & 295.7 & 27.5 & 8.7 & 111 & 4.2 \\
\hline
\end{tabular}

Note: Tree genera are Dacryodes and Manilkara; the palm genus is Prestoea.

$\dagger \mathrm{W}-=$ wood removal, $\mathrm{C}=$ control plots, and $\mathrm{W}+=$ wood addition.

\$ Understory palms were $<2 \mathrm{~m}$ in height, and overstory palms were $>2 \mathrm{~m}$ in height.

wood treatment effects by catchment and topographic location, as appropriate, were conducted on Phase 2 data only for all ecosystem parameters.

For most parameters (i.e., tree basal area increase [BAI], palm frond turnover rates, and litter production), sampling period was treated as a repeated measure and modeled as a split-plot in time. For fine-root biomass parameters, sampling period was modeled as an additional factor in the multiway factorial in a completely randomized design because root sampling was destructive, and thus measurements taken in different periods were not repeated measures on the same sampling unit. Tukey post-hoc pairwise comparisons ( $t$ tests) were used to determine mean differences.

Data are presented for D. excelsa and $M$. bidentata coarse-wood chemical composition and decay rates. Previously published papers have reported leaf, fineroot, and small-wood chemistry and decay rates of $D$. excelsa, M. bidentata, and P. montana (Bloomfield 1993, Bloomfield et al. 1993, Vogt et al. 1996). We statistically compared coarse-wood decay rates to leaf, root, and small-wood decay rates by tissue and topographic location. To conduct these analyses, we used one-way ANOVAs with Tukey-adjusted pairwise mean comparisons. We also present a summary of the available information on the initial chemical composition of these different tissues by species (Table 3 ).

When necessary, data were log-transformed prior to analysis to meet assumptions of normality and homogeneity of variances. Significant differences were accepted at $P<0.05$ and $P$ values are reported. All values reported are means $\pm 1 \mathrm{SE}$. Computations were conducted using SAS version 9 for Windows (SAS Institute, Cary, North Carolina, USA).

\section{RESULTS}

\section{Tree and palm growth rates}

Trees.-Aboveground BAI greatly varied among catchments $\left(F_{2,128}=6.45, P=0.0021\right.$; Fig. 1$)$. The catchment with significantly more $\mathrm{NO}_{3}{ }^{-}-\mathrm{N}$ in the soil and soil moisture (B5) had over twice the increase in basal area over the study period compared to the catchment with the least amount of available $\mathrm{NO}_{3}{ }^{-} \mathrm{N}$ and driest soil (EV) (Table 1). Aboveground BAI only slightly changed in response to the droughts and hurricane events that occurred between 1995 and 1998 . The droughts of 1996 and 1997 suppressed aboveground growth, as measured by BAI, whereas Hurricanes Bertha and Hortense increased aboveground growth $\left(F_{2,256}=42.58, P<0.0001\right)$, although this difference in growth rates was least dramatic in the most productive catchment (B5) $\left(F_{4,256}=3.31, P=\right.$ 0.012).

In EV, none of the trees marked in 1994 were missing or had died by June 1998 before Hurricane Georges. When the trees were remeasured in $2003,33 \%$ of the trees in EV had died with a mean annual mortality rate of $6.7 \%$ from 1998 to 2003 . In Bisley, $21 \%$ of marked trees in 1994 had died by 1998 resulting in a mean annual mortality rate of $5.3 \%$. By $2003,38 \%$ of the remaining marked trees died producing a mean annual mortality rate of $9.3 \%$.

At the initiation of the CWD experiment, there was no tree basal area difference by treatment $\left(F_{2,8}=3.41\right.$, $P=0.14)$. All three catchments responded similarly to the treatments $\left(F_{4,128}=0.01, P=0.99\right)$. Experimental addition of coarse wood stimulated BAI; however, treatment differences were only significant following Hurricanes Bertha and Hortense and were not 
TABLE 2. Extended.

\begin{tabular}{ccc}
\hline \hline & Palms \\
\hline $\begin{array}{c}\text { Overstory } \\
\text { density } \\
\text { (no. stems/ha) }\end{array}$ & $\begin{array}{c}\text { Overstory } \\
\text { aboveground } \\
\text { biomass (Mg/ha) }\end{array}$ & $\begin{array}{c}\text { P. montana } \\
\text { relative } \\
\text { importance }\end{array}$ \\
\hline & & \\
144 & 12.1 & 9.7 \\
222 & 18.6 & 19.9 \\
222 & 15.2 & 19.1 \\
& & \\
111 & 9.3 & 6.0 \\
100 & 5.3 & 15.8 \\
67 & 4.0 & 7.0 \\
& & \\
200 & 16.8 & 3.5 \\
178 & 14.9 & 3.8 \\
133 & 9.1 & \\
\hline
\end{tabular}

significant during drought events when BAI was minimal $\left(F_{4,256}=3.00, P=0.012\right.$; Fig. 2$)$.

Palms.-Palms at EV were, on average, taller $\left(F_{2,81}\right.$ $=6.26, P=0.0030)$ with more fronds $\left(F_{2,81}=4.20\right.$, $P=0.018)$ than at the Bisley sites. Palm frond turnover rates (the number of fronds senesced minus the new fronds produced) did not differ among catchments over the study period $\left(F_{2,81}=2.43, P=0.095\right)$. In addition, the number of palm shoots (fronds not fully expanded) produced did not differ among catchments $\left(F_{2,81}=2.87\right.$, $P=0.062$ ).

During the experiment, the number of palms directly hit by falling trees or that died from unknown causes did not differ by treatment or catchment (Appendix).
However, damage from Hurricane Georges was more severe at some catchments than at others. The B3 site had more broken fronds than the other catchments $\left(F_{2,81}\right.$ $=5.60, P=0.0053)$. At B5, palm mortality mostly occurred following Georges (catchment $\times$ time interaction, $F_{6,233}=2.34, P=0.032$ ). In addition, many palms at B5 were buried following Georges by fallen vines from canopy trees (catchment $\times$ time interaction, $\left.F_{6,233}=3.19, P=0.0050\right)$, although these palms often survived.

Coarse-wood treatments appeared to influence palm frond turnover rates $\left(F_{2,81}=7.53, P=0.0010\right.$; Fig. 3$)$. Turnover rates were greater in wood-addition plots than in the control or wood-removal plots $(\mathrm{t}=2.94, P=$ $0.012 ; \mathrm{t}=3.67, P=0.0013$, respectively). There was also a greater number of live fronds $\left(F_{2,81}=5.57, P\right.$ $=0.0054)$, a lower number of senesced fronds $\left(F_{2,81}=\right.$ 4.88, $P=0.010)$, and greater number of new palm shoots $\left(F_{2,81}=3.65, P=0.030\right)$ in the wood-addition plots than in the other treatments (Appendix).

\section{Litterfall}

Litterfall categories (leaves, fine wood, palm rachis, and reproductive plant parts) varied in their amount and percentage of total litterfall over time (Fig. 4). For example, following Hurricane Hugo, trees invested less in reproductive parts such as flowers and fruits (the "other" category) when it was $6 \%$ of the total litter than following a drought when it was $50 \%$ of the total litter. Conversely, leaves were $58 \%$ of the total litterfall following Hugo whereas five years after Hugo, leaves were $29 \%$ of the total litterfall. From 1989 to 1992

TABle 3. Summary of the predecomposition chemical composition of Dacroydes excelsa, Prestoea montana, and Manilkara bidentata plant parts.

\begin{tabular}{|c|c|c|c|c|c|c|}
\hline \multirow{2}{*}{$\begin{array}{l}\text { Species and } \\
\text { plant part }\end{array}$} & \multicolumn{5}{|c|}{ Plant chemical composition $(\%) \dagger$} & \multirow[b]{2}{*}{ Reference } \\
\hline & Nitrogen & Carbon & Lignin & Polyphenolics & Tannin binding & \\
\hline \multicolumn{7}{|l|}{ D. excelsa } \\
\hline Leaves & $0.57^{\mathrm{a}}(<0.01)$ & $44.3^{\mathrm{a}}(<0.01)$ & $11.8^{\mathrm{a}}(0.12)$ & $11.8^{\mathrm{a}}(0.25)$ & $14.5^{\mathrm{a}}(0.16)$ & Bloomfield (1993) \\
\hline Fine roots & $1.60^{\mathrm{b}}(<0.01)$ & $51.1^{\mathrm{b}}(0.02)$ & $28.7^{\mathrm{b}}(0.17)$ & $0.35^{\mathrm{b}}(<0.01)$ & $\operatorname{trace}^{\mathrm{b}}$ & Bloomfield (1993) \\
\hline Coarse wood & $0.08^{\mathrm{c}}(<0.01)$ & $38.0^{\mathrm{c}}(0.03)$ & $23.8^{\mathrm{b}}(0.19)$ & $\cdots$ & $\cdots$ & $\begin{array}{l}\text { Scatena et al. (1993) } \\
\text { (N, C); this study } \\
\text { (lignin) }\end{array}$ \\
\hline \multicolumn{7}{|l|}{ P. montana } \\
\hline Leaves & $1.15^{\mathrm{d}}(<0.01)$ & $42.2^{\mathrm{d}}(<0.01)$ & $16.1^{\mathrm{c}}(0.29)$ & $1.9^{\mathrm{c}}(<0.01)$ & trace $^{b}$ & Bloomfield (1993) \\
\hline Fine roots & $0.90^{\mathrm{e}}(0.01)$ & $47.1^{\mathrm{e}}(0.01)$ & $26.8^{\mathrm{b}}(0.25)$ & $2.0^{\mathrm{c}}(<0.01)$ & trace $^{\mathrm{b}}$ & Bloomfield (1993) \\
\hline \multicolumn{7}{|l|}{ M. bidentata } \\
\hline Leaves & $0.8^{\mathrm{f}}(<0.01)$ & $56.4^{\mathrm{f}}(0.10)$ & $21.7^{\mathrm{b}}(0.40)$ & $18.7^{\mathrm{d}}(0.22)$ & $\ldots$ & Bloomfield (1993) \\
\hline Fine roots & $1.4^{\mathrm{g}}(0.01)$ & $56.1^{\mathrm{f}}(0.03)$ & $34.4^{\mathrm{d}}(0.20)$ & $8.5^{\mathrm{e}}(0.07)$ & $\ldots$ & Bloomfield (1993) \\
\hline Coarse wood & $0.13^{\mathrm{h}}(<0.01)$ & $49.2^{\mathrm{g}}(<0.01)$ & $24.2^{\mathrm{b}}(0.23)$ & $\ldots$ & $\cdots$ & $\begin{array}{l}\text { J. Macy and W. Mc- } \\
\text { Dowell personal } \\
\text { communication } \\
(\mathrm{N}, \mathrm{C}) \text {; this study } \\
\text { (lignin) }\end{array}$ \\
\hline
\end{tabular}

Notes: Data are means (with SE in parentheses). Sample sizes, by reference, are: Bloomfield (1993), $n=10$; Scatena et al. (1996), $n=6$; this study, $n=8$; J. Macy and W. McDowell (personal communication), $n=2$.

$\dagger$ Those numbers follwed by the same lowercase letter are not significantly different in comparisons of a specific chemical composition across tissue types, using Tukey's studentized range test. 


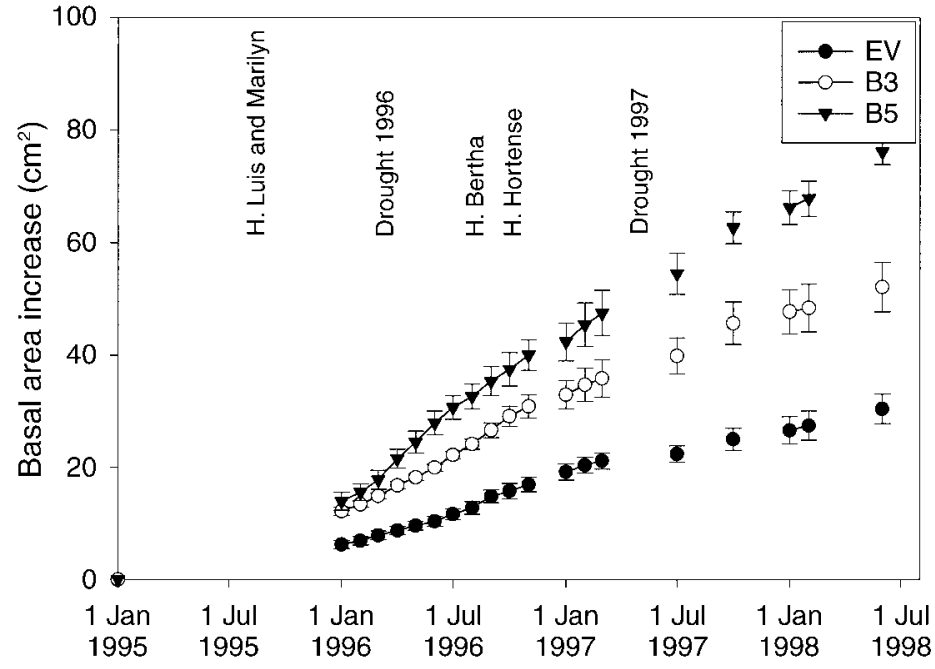

FIG. 1. Basal area increase (means $\pm \mathrm{SE}$ ) at El Verde (EV) and Bisley watersheds number 3 (B3) and number 5 (B5) in the Luquillo Experimental Forest, Puerto Rico, plotted with major disturbance events (H., hurricane). Basal area was measured on 18 trees in three plots per catchment $(n=3)$. palm rachises were $<1 \%$ of the litter and from 1994 to 1998 they were $12 \%$ of the total litter.

The amount of total litterfall varied with weather events throughout Phases 1 and $2\left(F_{8,152}=154.42, P\right.$ $<0.0001)$. In general, we found that hurricane wind speeds were positively associated with litterfall, and precipitation during droughts was negatively associated with litterfall (Fig. 5). There was a significant interaction between catchment and disturbance for all litter categories (leaves, $F_{10,405}=8.17, P<0.0001$; wood, $F_{10,405}=2.89, P=0.0017$; rachis, $F_{10,405}=6.13$, $P<0.0001$; other, $\left.F_{10,405}=7.95, P<0.0001\right)$. The B5 site produced more litter during some disturbance events (i.e., the drought of 1994 and Hurricane Bertha), but produced less litter during Hortense (a hurricane that hit two months after Bertha) than the other catchments. We also found some strong interactions between topography and disturbance. Less litterfall was generally transferred into the streams than the other topographic locations, and stream litterfall levels fluctuated more in response to some disturbance events (the drought of 1994 and Hurricane Bertha) than the other locations (leaves, $F_{10,405}=3.60, P<0.0001$; other, $F_{10,405}=4.14, P<0.0001$; Fig. 6).

More leaves and reproductive plant parts fell in the control and wood-addition plots than in the wood-removal plots $\left(F_{2,81}=3.33, P=0.040 ; F_{2,81}=3.85, P\right.$ $=0.025$, respectively), but there were no differences in litter input among the experimental treatments for the wood or palm rachis categories $\left(F_{2,81}=0.19, P=\right.$ $0.83 ; F_{2,81}=1.93, P=0.30$, respectively).

\section{Fine-root biomass}

The amount of live and dead fine-root biomass changed significantly with weather events (live, $F_{7,151}$ $=30.96, P<0.0001$; dead, $F_{7,151}=22.48, P<0.0001$; Fig. 7). Live root biomass was greatest pre-Hugo and during the post-Hugo and 1991 droughts. Live roots were lowest following the prolonged drought of 1994. Dead root biomass was greatest following Hugo and during the post-Hugo and the 1991 droughts; otherwise the amount of dead roots did not change with disturbances.

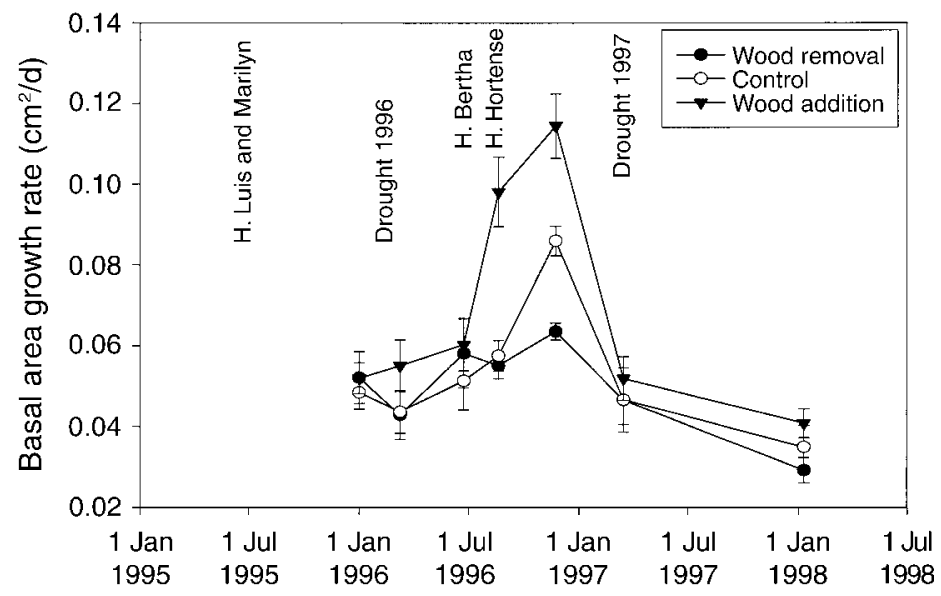

FIG. 2. Rate of basal area increase (means $\pm \mathrm{SE}$ ) by wood treatment in El Verde, Bisley 3, and Bisley 5 in the Luquillo Experimental Forest, Puerto Rico, plotted with major disturbance events ( $n=3$; H., hurricane). 


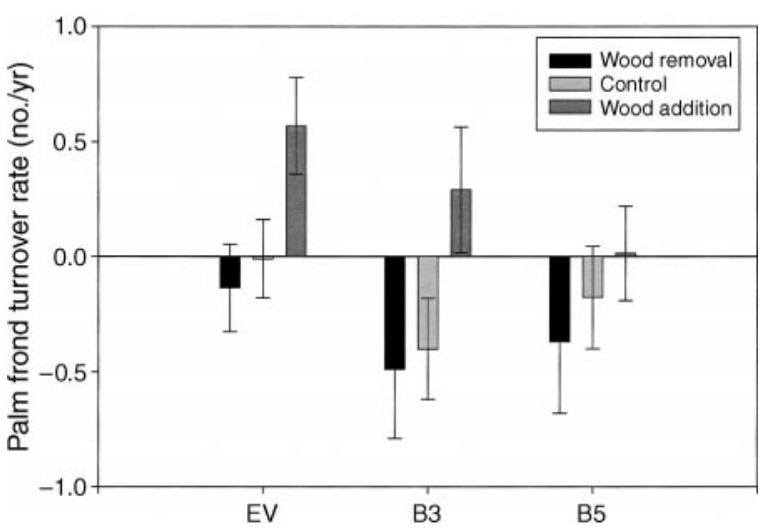

FIG. 3. Palm frond turnover rate (means $\pm \mathrm{SE}$ ) by treatment in El Verde (EV), Bisley 3 (B3), and Bisley 5 (B5) in the Luquillo Experimental Forest, Puerto Rico, from 1995 to $2000(n=10)$.

In Phase 2 of the experiment, there were more live and dead roots in EV (total roots, $340 \pm 13 \mathrm{~g} / \mathrm{m}^{2}$ ) than in either Bisley catchment (B3, $205 \pm 9$; B5, $204 \pm$ $12 \mathrm{~g} / \mathrm{m}^{2}$ ) (live, $F_{2,39}=15.24, P<0.0001$; dead, $F_{2,39}$ $=23.84, P<0.0001)$. Live and dead root biomass did not differ between upslope and riparian areas (live, $F_{2,39}$ $=0.010, P=0.93$; dead, $\left.F_{2,39}=0.67, P=0.41\right)$.

In addition to differences among catchments, the catchments responded differently to the CWD treatments (catchment $\times$ treatment interaction, live, $F_{4,39}=$ $3.09, P=0.027$; dead, $F_{4,39}=5.26, P=0.0017$ ). In both B5 and B3, live roots significantly increased with the wood-addition treatment; in B5, dead roots also significantly increased with wood-addition compared to control and wood-removal plots.

\section{Litter decomposition}

Leaf and root decay.-Dacryodes excelsa leaf decay rates initially showed differences by catchment and topography, but these differences did not persist after six months (Table 4). Decomposing fine roots did not show effects of catchment or topography on decay rates. Dacryodes excelsa leaves decayed at a significantly faster rate than fine roots after six months, but these differences did not exist after 12 months.

Palm tissues decayed more slowly than $D$. excelsa tissues. Palm frond decomposition was faster in streams than in terrestrial areas, but similar between catchments (EV and B3). Decay rates of palm fronds were significantly faster than roots at both 6 and 12 months. Roots decayed at a rate more similar to small wood than to leaves.

Small-diameter and coarse-wood decay.-Decay rates of $D$. excelsa small wood $(1-3 \mathrm{~cm}$ and $3-6 \mathrm{~cm}$ diameter) did not vary in riparian zones between $\mathrm{EV}$ and B3 (Table 4). However, differences were recorded in the upslope areas where EV had a slower decay rate (8.2 yr to $99 \%$ mass loss for the $1-3 \mathrm{~cm}$ diameter wood, $16.1 \mathrm{yr}$ for the $3-6 \mathrm{~cm}$ diameter wood) than B3 (3.8

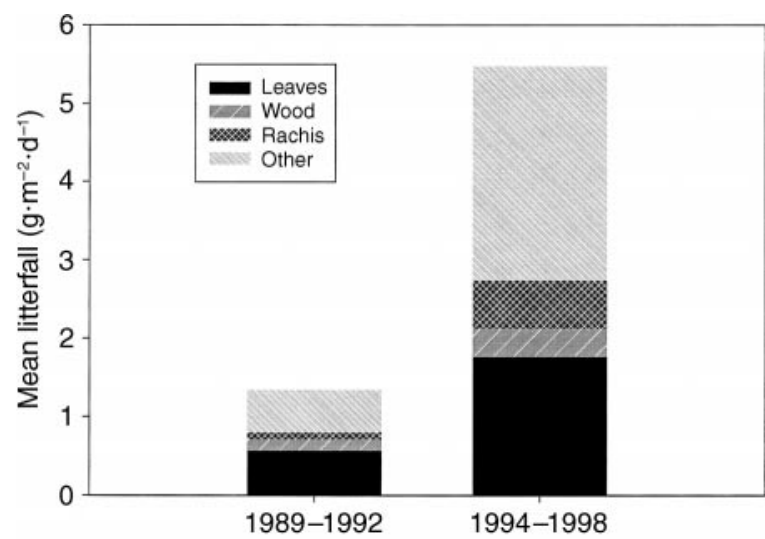

FIG. 4. Mean litterfall by leaf, fine wood, palm rachis, and other (mostly plant reproductive parts) categories in both El Verde and Bisley 3 in the Luquillo Experimental Forest, Puerto Rico.

yr for $99 \%$ mass loss for $1-3 \mathrm{~cm}$ diameter wood pieces, $6.7 \mathrm{yr}$ for the 3-6 cm diameter pieces; Vogt et al. 1996).

Dacryodes excelsa coarse-wood decay rates did not differ among catchments, but they did differ by location within catchments; decay rates were slower in streams
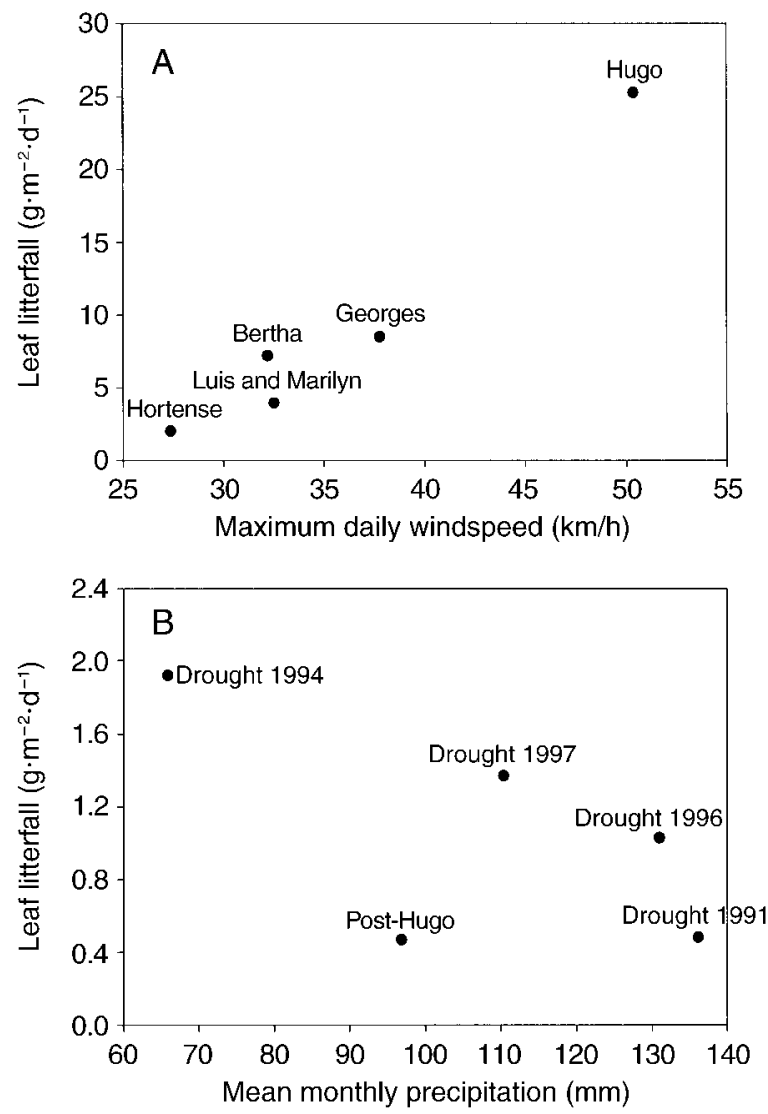

FIG. 5. Mean leaf litterfall vs. (A) maximum daily wind speeds during hurricane events and (B) mean monthly precipitation during drought events. 


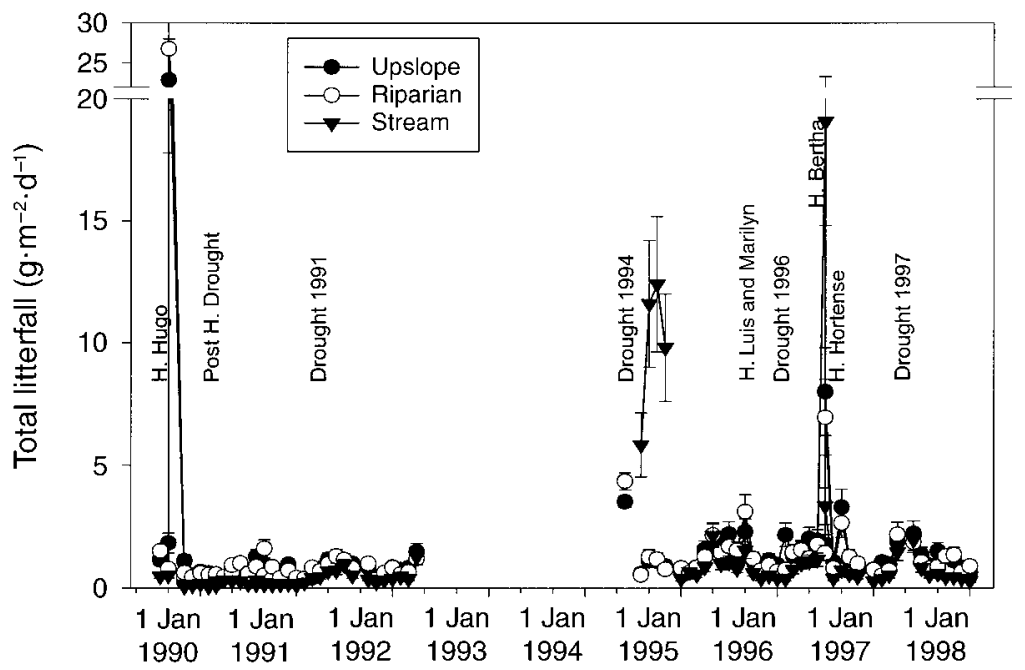

FIG. 6. Total litterfall (means $\pm \mathrm{SE}$ ) by topographic location at El Verde and Bisley 3, Luquillo Experimental Forest, Puerto Rico, plotted with major disturbance events.

than terrestrial areas. Manilkara bidentata coarse-wood decay rates during the three years of the study did not differ by topography, and its decay rate was very slow compared to $D$. excelsa.

\section{DISCUSSION}

Determining the level of resistance and recovery times of ecosystem indicators to different types of natural disturbance events can have profound implications on the way ecosystems are understood and modeled. We monitored ecosystem structure and function over a 10-year period to determine resistance and recovery rates to hurricane and drought events. Similar to other studies, we found that ecosystem functions, such as plant growth rates and decomposition rates, recovered faster than ecosystem structures, such as foliage and fine-root biomass, following disturbance (Bowden et al. 1993, Foster et al. 1999). We also found that resistance and resilience of the measured response variables depended on the type (weather-related, such as hurricane or drought, or structural, the addition of coarse woody debris) and intensity of the disturbance. Smallmagnitude disturbances had less of an influence on ecosystem parameters than large-magnitude disturbances. Finally, we found that for some parameters, in particular those representing changes in nutrient availability, site legacies had a greater influence over the parameter than did any type of natural disturbance event.

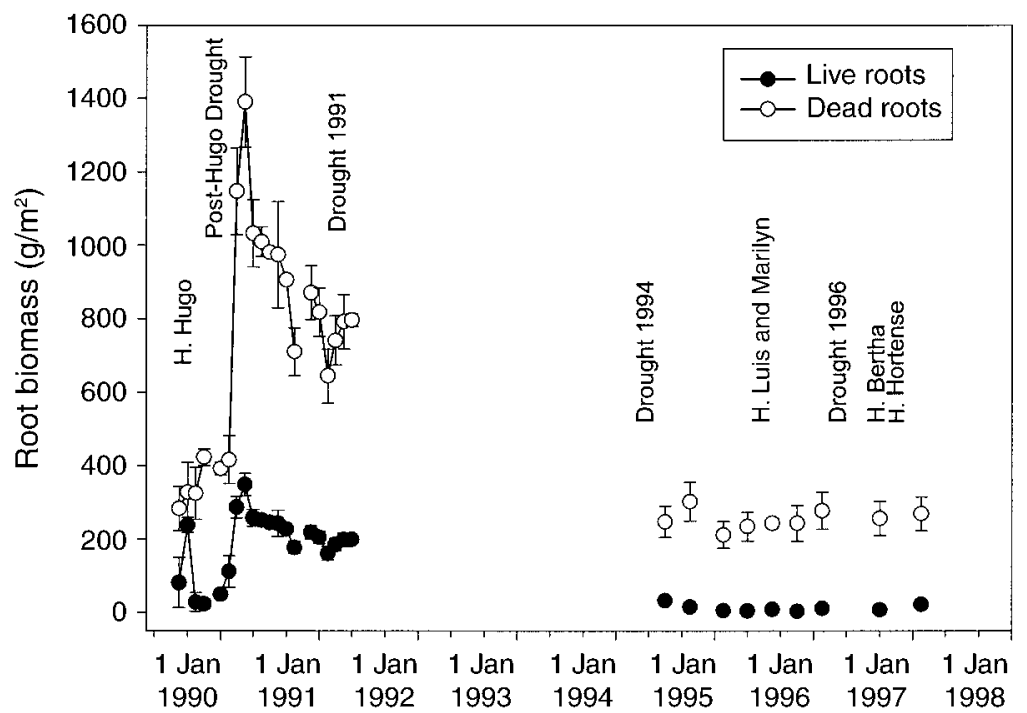

FIG. 7. Live and dead fine-root biomass (means \pm SE) from El Verde and Bisley 3 in the Luquillo Experimental Forest, Puerto Rico, plotted with major disturbance events. The amounts of live and dead roots were estimated from total roots from May 1990 to March 1991. 


\section{Ecosystem indicators respond to weather}

Trees and palms.- Tree and palm growth rates were generally maintained despite weather events. The mean BAI of dendrometer-banded trees within a plot remained remarkably stable from 1994 to $1998\left(R^{2}=\right.$ $97.8 \pm 0.3$ rate of increase by plot over time). Tree diameter growth rates increased slightly with Hurricanes Bertha and Hortense, which may have resulted from increased growing space, precipitation, or nutrient availability from the foliage transfer. However, because the increase in growth was least at the catchment (B5) where damage was greatest, it is unlikely that hurricane-associated damage alone explains post-hurricane growth rates. As expected, tree diameter growth slowed at all catchments during droughts. However, these weather-induced fluctuations were small compared to the large growth rate differences found among catchments.

Hurricane damage does not appear to explain growth rate differences among catchments. While the Bisley sites receive more hurricane damage than $\mathrm{EV}$ (Boose et al. 1994), a significant amount of new growing space did not materialize at these sites. The production of new growing space was minimal because trees often had broken tops that resprouted or produced new foliage within a month and, for the trees that died, mortality was often delayed more than a year (Lugo and Scatena 1996). It might be expected that the amount of litter transferred to the forest floor with hurricanes explains growth rate differences. There was a pulse of $\mathrm{N}$ recorded in the streams after Hurricane Hugo (Silver and Vogt 1993), but again this pulse only lasted for a month. Site conditions, rather than specific or cumulative effects of disturbances, appear to control the consistent growth rate differences among the catchments.

Palms can be completely defoliated during intense hurricane events (Basnet et al. 1992), which we observed following Hugo when palm litter was greatly reduced. However, when disturbances are less intense, palms are thought to be resistant (McCormick 1996). Indeed, we found that palm litter was less responsive than tree leaf fall to most hurricane events. The resilience of palms to weather events was also apparent when we compared the loss and growth of new palm fronds from 1995 to 2000 . We found no significant difference between the number of fronds lost and the number of fronds produced each year $(1.90 \pm 0.08$ and $1.87 \pm 0.05$ fronds, respectively) despite the droughts and hurricanes that occurred.

Our tree mortality rates are similar to those found in other studies following hurricanes (Lugo and Scatena 1996); however, they are greater (4-8\%/yr) than what has been estimated for periods between major disturbance events (2-5\%/yr) (Lugo and Waide 1993). As expected, the Bisley catchments had higher tree and palm mortality rates and more structural damage than $\mathrm{EV}$; however, the Bisley catchments also had greater recovery rates. Hurricane Georges caused more broken palm fronds at B3, yet this catchment had the greatest rate of new frond production (Appendix). In addition, BAI was greater at the Bisley catchments than EV. Structural changes, such as the number of broken palm fronds and tree mortality, appear to be better indicators of hurricane disturbance than measures of growth rates under the disturbance regimes experienced by these forests. However, estimating structural damage and mortality can be difficult because of resprouting and root grafting (Basnet et al. 1993), delayed responses (Walker 1995), and interactive effects between disturbance events (Shaw 1983).

Litterfall.-Our litterfall rates were similar to those found in earlier studies (Lugo and Scatena 1995). Of the variables we measured, litterfall was the most responsive to weather events. The general positive relationship between hurricane wind speeds and litterfall and negative relationship between precipitation during droughts and litterfall were expected because litterfall is known to be responsive to these factors (Brown and Lugo 1982). These relationships did not hold well only for the post-Hugo drought (Fig. 5) because there was low canopy biomass following the hurricane and, therefore, less foliage to be transferred to the forest floor. This example illustrates the potential difficulties in studying disturbance events in isolation.

Our litterfall results highlight the importance of sampling multiple topographic locations to determine disturbance responses. Litterfall in the stream zones had a greater response to weather events, such as the drought of 1994 and Hurricane Bertha, than the riparian and upslope areas (Fig. 6). In addition, litter production increased over the streams immediately in response to Hurricane Bertha, while litter production in terrestrial areas did not respond for two weeks. These differences suggest that stream areas are a better indicator of hurricane and drought events than terrestrial areas. This might be expected, at least during droughts, because plants living near streams are likely to be more adapted to high water environments and may be more stressed during times of low water availability. On the other hand, fallen debris may be greater, and more immediate, in streams than in terrestrial areas because there is less structure to impede litter transfer.

Areas above streams also had slower litter production recovery following disturbance than terrestrial areas. For example, terrestrial areas reestablished litter inputs to pre-Hugo levels faster than streams. In addition, shortly after Hurricane Bertha, when Hortense passed through the forest, the streams measured no litter response, while the terrestrial areas increased inputs. Different responses by topographic location may be important for understanding how components of the ecosystem recover from disturbances. For example, the idea that plants growing near streams have less resilience and slower recovery following disturbances may influence the recovery of aquatic community dynamics 
TABle 4. Decomposition rates for Dacroydes excelsa, Prestoea montana, and Manilkara bidentata plant parts in stream pools, riparian zones, and upslope areas at El Verde, Bisley 3, and Bisley 5, Luquillo Experimental Forest, Puerto Rico.

\begin{tabular}{|c|c|c|c|c|c|c|}
\hline \multirow{3}{*}{$\begin{array}{c}\text { Species and plant } \\
\text { part, by } \\
\text { study area }\end{array}$} & \multirow[b]{3}{*}{ Source $\dagger$} & & & \multicolumn{3}{|c|}{ Mass loss $(\%) \ddagger$} \\
\hline & & \multicolumn{2}{|c|}{ Decay period } & \multicolumn{3}{|c|}{ Stream } \\
\hline & & No. months & Dates & Mean & SE & $n$ \\
\hline \multicolumn{7}{|l|}{ El Verde } \\
\hline \multirow[t]{2}{*}{ Leaves } & 1,2 & 6 & $6 / 1989-12 / 1989$ & $63.1^{\mathrm{aA}}$ & 5.9 & 10 \\
\hline & & 12 & 6/1989-6/1990 & $99.9^{\mathrm{aB}}$ & 0.1 & 10 \\
\hline \multirow[t]{2}{*}{ Fine roots } & 1,2 & 6 & $6 / 1989-12 / 1989$ & $46.8^{\mathrm{aC}}$ & 3.4 & 10 \\
\hline & & 12 & 6/1989-6/1990 & $99.5^{\mathrm{aB}}$ & 0.1 & 10 \\
\hline \multirow[t]{2}{*}{ Small wood } & 3 & 6 & 11/1989-5/1990 & $\cdots$ & $\cdots$ & $\ldots$ \\
\hline & & 12 & $11 / 1989-11 / 1990$ & $\ldots$ & $\ldots$ & $\ldots$ \\
\hline \multirow{2}{*}{ Medium wood } & 3 & 6 & $11 / 1989-5 / 1989$ & $\ldots$ & $\cdots$ & $\ldots$ \\
\hline & & 12 & $11 / 1989-11 / 1990$ & $\ldots$ & $\ldots$ & $\ldots$ \\
\hline \multirow[t]{3}{*}{ Coarse wood } & 4 & 15 & 1/1995-4/1996 & $16^{\mathrm{aD}}$ & 2.8 & 2 \\
\hline & & 24 & 1/1995-1/1997 & $\ldots$ & $\ldots$ & $\ldots$ \\
\hline & & 36 & $1 / 1995-1 / 1998$ & 19 & $\cdots$ & 1 \\
\hline \multicolumn{7}{|l|}{ P. montana } \\
\hline \multirow[t]{2}{*}{ Leaves } & 1,2 & 6 & $6 / 1989-12 / 1989$ & $85.9^{\mathrm{aE}}$ & 1.9 & 10 \\
\hline & & 12 & 6/1989-6/1990 & $79.2^{\mathrm{aE}}$ & 1.8 & 10 \\
\hline \multirow[t]{2}{*}{ Fine roots } & 1,2 & 6 & $6 / 1989-12 / 1989$ & $27.5^{\mathrm{aF}}$ & 3.1 & 10 \\
\hline & & 12 & 6/1989-6/1990 & $48.5^{\mathrm{aC}}$ & 1.8 & 10 \\
\hline \multicolumn{7}{|l|}{ M. bidentata } \\
\hline \multirow[t]{3}{*}{ Coarse wood } & 4 & 15 & $1 / 1995-4 / 1996$ & 8 & $\cdots$ & 1 \\
\hline & & 24 & 1/1995-1/1997 & $4^{\mathrm{aG}}$ & 1.5 & 4 \\
\hline & & 36 & 1/1995-1/1998 & $2^{\mathrm{aG}}$ & 3.2 & 8 \\
\hline \multicolumn{7}{|l|}{ Bisley 3} \\
\hline D. excelsa & & & & & & \\
\hline Leaves & 1,2 & 6 & 6/1989-12/1989 & $78.9^{\mathrm{aE}}$ & 2.5 & 10 \\
\hline & & 12 & 6/1989-6/1990 & $>99.9^{\mathrm{aB}}$ & $<0.1$ & 10 \\
\hline Fine roots & 1,2 & 6 & $6 / 1989-12 / 1989$ & $49.9^{\mathrm{aC}}$ & 4.9 & 10 \\
\hline & & 12 & 6/1989-6/1990 & $99^{\mathrm{aB}}$ & 0 & 10 \\
\hline Small wood & 3 & 6 & $11 / 1989-5 / 1990$ & $\ldots$ & $\ldots$ & $\ldots$ \\
\hline & & 12 & 11/1989-11/1990 & $\ldots$ & $\cdots$ & $\ldots$ \\
\hline Medium wood & 3 & 6 & 11/1989-5/1989 & $\cdots$ & $\cdots$ & .. \\
\hline & & 12 & $11 / 1989-11 / 1990$ & $\ldots$ & $\ldots$ & $\ldots$ \\
\hline Coarse wood & 4 & 15 & 1/1995-4/1996 & $22^{\mathrm{F}}$ & 3.5 & 8 \\
\hline & & 24 & 1/1995-1/1997 & $\cdots$ & $\cdots$ & $\ldots$ \\
\hline & & 36 & $1 / 1995-1 / 1998$ & $32^{\mathrm{aF}}$ & 6.7 & 6 \\
\hline P. montana & & & & & & \\
\hline Leaves & 1,2 & 6 & 6/1989-12/1989 & $82.5^{\mathrm{aE}}$ & 1.8 & 10 \\
\hline & & 12 & $6 / 1989-6 / 1990$ & $93.2^{\mathrm{B}}$ & $\cdots$ & 10 \\
\hline Fine roots & 1,2 & 6 & $6 / 1989-12 / 1989$ & $38.5^{\mathrm{aF}}$ & 3.0 & 10 \\
\hline & & 12 & 6/1989-6/1990 & $48.5^{\mathrm{aC}}$ & 1.8 & 10 \\
\hline M. bidentata & & & & & & \\
\hline Coarse wood & 4 & 15 & 1/1995-4/1996 & $7^{\mathrm{G}}$ & 2.2 & 5 \\
\hline & & 24 & 1/1995-1/1997 & $12^{\mathrm{aG}}$ & 0.3 & 2 \\
\hline & & 36 & 1/1995-1/1998 & $14^{\mathrm{aG}}$ & 6.0 & 4 \\
\hline Bisley 5 & & & & & & \\
\hline D. excelsa & & & & & & \\
\hline Coarse wood & 4 & 15 & 1/1995-4/1996 & $23^{\mathrm{aF}}$ & 4.2 & 2 \\
\hline & & 24 & $1 / 1995-1 / 1997$ & 39 & $\ldots$ & 1 \\
\hline & & 36 & 1/1995-1/1998 & $\cdots$ & $\cdots$ & $\cdots$ \\
\hline M. bidentata & & & & & & \\
\hline Coarse wood & 4 & 15 & 1/1995-4/1996 & $12^{\mathrm{G}}$ & 2.3 & 7 \\
\hline & & 24 & $1 / 1995-1 / 1997$ & $7^{\mathrm{G}}$ & 0.2 & 3 \\
\hline & & 36 & $1 / 1995-1 / 1998$ & 0 & $\cdots$ & 1 \\
\hline
\end{tabular}

$\dagger$ Key to sources: 1, Bloomfield (1993); 2, Bloomfield et al. (1993); 3, Vogt et al. (1996); 4, this study.

$\$$ Mean values followed by the same lowercase letters are not significantly different in comparisons of the same tissue type decomposing in the stream, riparian, and upslope areas (one-way ANOVAs with Tukey's comparisons of means, $P<$ 0.05.). Mean values followed by the same uppercase letters are not significantly different when comparing across tissue types by location (i.e., stream) (one-way ANOVAs with Tukey's comparisons of means, $P<0.05$ ). Statistical comparisons of coarse-wood decay rates were calculated with decay time when sufficient data existed; when followed by the same uppercase letters, these values are not significantly different $(P<0.05)$. 
TABLe 4. Extended.

\begin{tabular}{|c|c|c|c|c|c|}
\hline \multicolumn{6}{|c|}{ Mass loss $(\%) \ddagger$} \\
\hline \multicolumn{3}{|c|}{ Riparian } & \multicolumn{3}{|c|}{ Upslope } \\
\hline Mean & SE & $n$ & Mean & $\mathrm{SE}$ & $n$ \\
\hline $47.5^{\mathrm{bA}}$ & 1.0 & 10 & $46.6^{\mathrm{bA}}$ & 2.6 & 10 \\
\hline $99.9^{\mathrm{aB}}$ & 0.1 & 10 & $>99.9^{\mathrm{aB}}$ & $<0.1$ & 10 \\
\hline $28.0^{\mathrm{aC}}$ & 7.9 & 10 & $35.3^{\mathrm{aA}}$ & 3.3 & 10 \\
\hline $99.8^{\mathrm{aB}}$ & 0.1 & 10 & $>99.9^{\mathrm{aB}}$ & $<0.1$ & 10 \\
\hline $29.2^{\mathrm{aC}}$ & 0.3 & 10 & $27.5^{\mathrm{aC}}$ & 0.3 & 10 \\
\hline $26.8^{\mathrm{aC}}$ & 3.1 & 10 & $27.5^{\mathrm{aC}}$ & 2.2 & 10 \\
\hline $4.1^{\mathrm{aD}}$ & 0.6 & 10 & $1.2^{\mathrm{bD}}$ & 0.4 & 10 \\
\hline $3.9^{\mathrm{aD}}$ & 2.3 & 10 & $1.2^{\mathrm{bD}}$ & 1.2 & 10 \\
\hline $45^{\mathrm{bA}}$ & 4.0 & 3 & $\ldots$ & $\ldots$ & $\ldots$ \\
\hline $52^{\mathrm{A}}$ & 9.2 & 2 & $\ldots$ & $\ldots$ & $\ldots$ \\
\hline $64^{\mathrm{E}}$ & 1.0 & 4 & $\cdots$ & $\cdots$ & $\cdots$ \\
\hline $55.2^{\mathrm{bA}}$ & 1.4 & 10 & $55.9^{\mathrm{bE}}$ & 2.2 & 10 \\
\hline $67.9^{\mathrm{bE}}$ & 1.2 & 10 & $66.8^{\mathrm{bF}}$ & 2.1 & 10 \\
\hline $18.7^{\mathrm{aF}}$ & 3.5 & 10 & $26.3^{\mathrm{aC}}$ & 1.5 & 10 \\
\hline $36.3^{\mathrm{bC}}$ & 3.1 & 10 & $36.7^{\mathrm{bA}}$ & 2.2 & 10 \\
\hline $14^{\mathrm{aF}}$ & 3.5 & 3 & $8^{\mathrm{aD}}$ & 1.6 & 6 \\
\hline $2^{\mathrm{aD}}$ & 0.9 & 5 & $5^{\mathrm{aD}}$ & 1.6 & 6 \\
\hline $4^{\mathrm{aD}}$ & 5.7 & 2 & $18^{\mathrm{aD}}$ & 3.3 & 6 \\
\hline $49.8^{\mathrm{bA}}$ & 3.0 & 10 & $39.7^{\mathrm{bA}}$ & 2.8 & 10 \\
\hline $99.8^{\mathrm{aB}}$ & 0.9 & 10 & $99.9^{\mathrm{aB}}$ & $<0.1$ & 10 \\
\hline $34.8^{\mathrm{aC}}$ & 3.1 & 10 & $36.1^{\mathrm{aA}}$ & 2.5 & 10 \\
\hline $99.6^{\mathrm{aB}}$ & 0.2 & 10 & $99.8^{\mathrm{aB}}$ & 0.1 & 10 \\
\hline $19.9^{\mathrm{aF}}$ & 2.0 & 10 & $20.8^{\mathrm{aC}}$ & 0.9 & 10 \\
\hline $19.9^{\mathrm{aF}}$ & 3.2 & 10 & $16.9^{\mathrm{aG}}$ & 1.6 & 10 \\
\hline $30.7^{\mathrm{aC}}$ & 1.8 & 10 & $26.1^{\mathrm{aC}}$ & 1.3 & 10 \\
\hline $30.4^{\mathrm{aC}}$ & 2.8 & 10 & $26.1^{\mathrm{aC}}$ & 3.2 & 10 \\
\hline $34^{\cdots}$ & $\begin{array}{l}\cdots \\
5.8\end{array}$ & 5 & $40^{\mathrm{aA}}$ & $\begin{array}{l}\cdots \\
5.0\end{array}$ & $\begin{array}{c}\cdots \\
4\end{array}$ \\
\hline $59^{\mathrm{bA}}$ & 5.8 & 3 & $50^{\mathrm{bA}}$ & 7.5 & 4 \\
\hline $59.4^{\mathrm{bA}}$ & 2.0 & 10 & $46.7^{\mathrm{bA}}$ & 4.4 & 10 \\
\hline $68.7^{\mathrm{aE}}$ & 3.8 & 10 & $66.7^{\mathrm{aF}}$ & 3.3 & 10 \\
\hline $23.9^{\mathrm{bF}}$ & 2.5 & 10 & $27.9^{\mathrm{bC}}$ & 3.6 & 10 \\
\hline $40.9^{\mathrm{aA}}$ & 1.0 & 10 & $43.4^{\mathrm{aA}}$ & 3.5 & 10 \\
\hline$\ldots$ & $\ldots$ & $\ldots$ & $\ldots$ & $\ldots$ & $\ldots$ \\
\hline $0.0^{\mathrm{bD}}$ & 5.0 & 2 & $3^{\mathrm{bD}}$ & 2.8 & 2 \\
\hline $17^{\mathrm{aF}}$ & 5.8 & 3 & $11^{\mathrm{aD}}$ & 3.5 & 2 \\
\hline $42^{\mathrm{bA}}$ & 1.3 & 10 & $40^{\mathrm{bA}}$ & 2.7 & 5 \\
\hline $45^{\mathrm{aA}}$ & 2.9 & 6 & $57^{\mathrm{aA}}$ & 9.0 & 6 \\
\hline $58^{\mathrm{aA}}$ & 5.3 & 6 & $57^{\mathrm{aA}}$ & 5.3 & 7 \\
\hline$\ldots$ & $\ldots$ & $\ldots$ & 15 & $\ldots$ & 1 \\
\hline$\ldots$ & $\ldots$ & $\ldots$ & 0.0 & $\ldots$ & 1 \\
\hline$\ldots$ & $\ldots$ & $\ldots$ & $\ldots$ & $\ldots$ & $\cdots$ \\
\hline
\end{tabular}

that depend on litter for resources and habitat (Covich et al. 2003).

Hurricanes Hugo and Bertha and the drought of 1994 produced the greatest increases in litterfall, but litterfall was more resilient following the 30-year drought than the 60-year hurricane event (time refers to reoccurrence interval). Following Hugo, leaf litter production did not return to pre-disturbance levels for several years (Scatena et al. 1996, Vogt et al. 1996). In fact, there was little effect of one of the most significant drought events (post-Hugo) on litterfall deposition because the canopy had not recovered. However, following other hurricane events, such as Bertha, litterfall generally returned to pre-disturbance values within one month. Following the most influential drought (1994) during the study, litterfall above streams returned to pre-disturbance values within one month of normal rainfall. In general, litterfall response to disturbance was immediate, and litterfall rates usually recovered in time to be impacted by future disturbance events.

Fine roots.-Fine roots responded to hurricanes and droughts very differently. Following Hugo, when the majority of trees lost some photosynthetic capacity, root mortality occurred immediately and at very high levels so that root biomass was significantly lower than recorded prior to Hugo (Vogt et al. 1995). This high fine-root mortality was expected because of the extensive mortality of trees. In addition, the increase in production of new leaves and resprouting that occurred following Hugo would have resulted in less photosynthate available for root growth and maintenance. It appeared that fine-root biomass had recovered to prehurricane levels seven months following Hugo.

However, the largest increase in total fine-root biomass (mostly dead root biomass) was recorded eight months after Hugo (Fig. 7), which coincided with the onset of rainfall following the post-Hugo drought. Production of new fine roots at this time might be expected as plants need to increase their acquisition of nutrients to support the growth of new foliage (Kavanagh and Kellman 1992). Whether this peak in fine-root biomass was ultimately a function of the hurricane, the drought, or their interaction is indeterminable. This uncertainty again highlights the difficulty in linking an ecosystem response to any one event when multiple disturbances are common and responses are delayed (Vogt et al. 1997).

Fine roots appeared to have a greater response to the 30 -year drought than the 60-year hurricane. Following the 1994 drought, live fine-root biomass was only $9 \%$ of pre-disturbance (pre-Hugo) levels, whereas following Hugo it was $41 \%$ of pre-disturbance levels. We expected roots to be a sensitive indicator of drought, especially in the clayey soils in the study forest. A severe drought can result in a high rate of root mortality (Bloomfield et al. 1996), and new root growth will not occur until the drought is over, whereas new root growth can occur relatively quickly after a severe hurricane as long as some of the canopy is intact. Recovery of root biomass to the 1994 drought was so slow that it never recovered to pre-drought levels during the study. 
TABLE 5. Chemical composition (means with SE in parentheses) of Dacroydes excelsa and Manilkara bidentata coarse wood (10-80 cm in diameter) decomposing at different time intervals in three watersheds in the Luquillo Experimental Forest, Puerto Rico.

\begin{tabular}{|c|c|c|c|c|c|c|c|c|c|}
\hline \multirow{2}{*}{\multicolumn{2}{|c|}{$\begin{array}{l}\text { Decay period } \\
\text { by species }\end{array}$}} & \multicolumn{6}{|c|}{ Stream } & \multirow{2}{*}{\multicolumn{2}{|c|}{$\frac{\text { Riparian }}{\mathrm{N}}$}} \\
\hline & & \multicolumn{2}{|l|}{$\mathrm{N}$} & \multicolumn{2}{|l|}{$\mathrm{C}$} & \multicolumn{2}{|c|}{ Lignin } & & \\
\hline Mo. & Dates & $\%$ & $n$ & $\%$ & $n$ & $\%$ & $n$ & $\%$ & $n$ \\
\hline \multicolumn{10}{|c|}{ D. excelsa } \\
\hline 15 & 1/1995-4/1996 & 0.26 & 1 & ... & $\ldots$ & $24.43(3.04)$ & 2 & 0.37 & 1 \\
\hline 24 & $1 / 1995-1 / 1997$ & $\ldots$ & $\ldots$ & $\ldots$ & $\ldots$ & 22 & 1 & 0.29 & 1 \\
\hline 36 & $1 / 1995-1 / 1998$ & $0.21(0.00)$ & 2 & $49.35(0.12)$ & 2 & $\cdots$ & $\cdots$ & $0.28(0.02)$ & 3 \\
\hline \multicolumn{10}{|c|}{ M.bidentata } \\
\hline 15 & 1/1995-4/1996 & 0.26 & 1 & 49.7 & 1 & $21.6 \quad(0.72)$ & 3 & ... & $\ldots$ \\
\hline 24 & $1 / 1995-1 / 1997$ & $\ldots$ & $\ldots$ & $\ldots$ & $\ldots$ & $21.87(0.74)$ & 3 & $0.24(0.04)$ & 2 \\
\hline 36 & $1 / 1995-1 / 1998$ & $0.17(0.01)$ & 3 & $49.45(0.12)$ & 2 & & $\ldots$ & $0.23(0.02)$ & 2 \\
\hline
\end{tabular}

Note: Amount of decaying wood analyzed per watershed was $3.8 \pm 0.27$ pieces.

\section{Influence of coarse woody debris from hurricanes}

Severe hurricanes rapidly transfer large amounts of slowly decomposing wood to the forest floor. The addition of CWD to the forest floor is thought to temporarily limit plant production because microbes decomposing poor-quality litter compete with plants for available N (Sanford et al. 1991, Zimmerman et al. 1995). Thus, it might be expected that CWD additions increase nutrient immobilization in decomposing materials and decrease plant production. However, in the subtropics, where decomposition rates are fast even for large pieces of wood, CWD additions could make nutrients available to microbes and plants over a period of years.

We found that in all three catchments tree BAI and palm frond turnover rates increased with CWD additions during a four-year experiment. Increases in BAI in the wood-addition plots were especially greater than the other treatments following hurricane events, which were associated with high rainfall, some reduced overstory competition, and nutrient pulses to the soil. Our results differ from studies that used modeling tools to suggest that CWD deposited on the ground during a hurricane in Puerto Rico would lower aboveground plant growth for at least a few years and potentially until the following decade (Sanford et al. 1991, Zimmerman et al. 1995). Our results suggest that hurricanerelated wood additions may increase ecosystem recovery because of the extended rate of decomposition and associated release of nutrients.

Because CWD can immobilize nutrients, it has been thought that plant productivity as well as leaf senescence rates should decrease with coarse-wood additions. Some researchers have found reduced litterfall with the addition of CWD (Zimmerman et al. 1995, Walker et al. 1996). We found that litterfall was higher in control and wood-addition plots than in wood-removal plots, which further suggests that coarse-wood additions increased nutrient availability over the four years. It has been suggested that plants will not expend carbon on roots in high-nutrient conditions (Wilson and
Tilman 1991); accordingly, plants should not increase fine-root biomass if CWD increases nutrient availability. However, we found that fine-root biomass responded positively to the coarse-wood additions in the most productive catchments (B3, B5). Our results suggest that competing plants faced with increased nutrient availability responded by increasing their biomass and biotic demand, which resulted in increased fine-root biomass (Nadelhoffer 2000).

\section{Legacies influence how the ecosystem responds to disturbance}

Legacies that change an ecosystem's response to disturbance can be especially important in a frequently disturbed environment. In the LEF, we found that sitedependent legacies, resulting from past land use, buffer the recovery of ecosystem function following natural disturbance. For example, in all catchments tree BAI increased with hurricanes and CWD additions. However, these effects were least measurable at B5 where aboveground growth was much greater than at the other two catchments. The high productivity observed at B5 is likely a result of the higher amount of plant available $\mathrm{N}$ at the site (Table 1), which probably resulted from the site's land use history, namely, the planting of $\mathrm{N}_{2}$ fixing shade trees for a former coffee plantation. Therefore, it might be argued that land use legacies buffered B5 against future natural disturbances.

In these subtropical forests, nutrient availability is tightly linked with decomposition rates. Therefore, maintaining decay rates despite disturbances can greatly aid in ecosystem recovery (Vogt et al. 1996). We found that decay rates in the LEF were strongly chemical-based, were a function of species-specific chemistry, and did not vary with disturbance (Bloomfield 1993). For example, following Hurricane Hugo, tabonuco leaf and root decay rates were not altered by the microclimate changes that occurred by topography and catchment (Vogt et al. 1996). If plant tissue chemistry controls nutrient mineralization rates following hurricanes, this would greatly conserve nutrients be- 
TABle 5. Extended.

\begin{tabular}{|c|c|c|c|c|c|c|c|c|c|}
\hline \multicolumn{4}{|c|}{ Riparian } & \multicolumn{6}{|c|}{ Upslope } \\
\hline \multicolumn{2}{|l|}{$\mathrm{C}$} & \multicolumn{2}{|c|}{ Lignin } & \multicolumn{2}{|l|}{$\mathrm{N}$} & \multicolumn{2}{|l|}{$\mathrm{C}$} & \multicolumn{2}{|c|}{ Lignin } \\
\hline$\%$ & $n$ & $\%$ & $n$ & $\%$ & $n$ & $\%$ & $n$ & $\%$ & $n$ \\
\hline 49.5 & 1 & $23.65(0.94)$ & 2 & 0.23 & 1 & 49.7 & 1 & 24.3 & 1 \\
\hline$\ldots$ & $\ldots$ & $24.03(0.73)$ & 3 & 0.32 & 1 & 49.3 & 1 & $24.75(0.20)$ & 2 \\
\hline $49.53(0.18)$ & 3 & $\cdots$ & $\cdots$ & $0.33(0.03)$ & 2 & $49.60(0.24)$ & 2 & $\cdots$ & $\cdots$ \\
\hline$\ldots$ & $\ldots$ & 23 & 1 & $\ldots$ & $\ldots$ & $\ldots$ & $\ldots$ & 22.3 & 1 \\
\hline 49 & 1 & $22.90(0.08)$ & 2 & 0.18 & 1 & 49.6 & 1 & $23.90(1.6)$ & 2 \\
\hline $49.85(0.04)$ & 2 & $\ldots$ & $\ldots$ & $0.17(0.01)$ & 2 & $50(0.16)$ & 2 & $\ldots$ & $\ldots$ \\
\hline
\end{tabular}

cause nutrient flux would not occur when plant acquisition of soil resources is limited. We suggest that litter chemistry may be viewed as a chemical "legacy" that is important for maintaining ecosystem functioning and resiliency.

Because the decay rates of tissues varied by species, each species can perhaps be viewed as having a different capacity to conserve nutrients in the ecosystem. The dominant species, tabonuco, had significantly faster decay rates of its tissues compared to other common species. Tabonuco produces isoterpenes, which are likely to facilitate rapid decomposition. In comparison, palms produce polyphenolics that are likely to slow decomposition (Table 3 ). The slow decomposition rate of $M$. bidentata coarse wood may be due to the high C compound (i.e., lignin) concentration in its initial material (Table 3 ) and its low $\mathrm{N}$ concentrations $(0.2 \%$; Table 5). Species such as tabonuco, which are associated with rapid nutrient turnover, may decrease recovery times relative to other species, such as palms and $M$. bidentata, that may provide important nutrient sources over the longer term.

\section{CONCLUSIONS}

We found that, following weather disturbances, ecosystem structure (e.g., roots, tree canopies) recovered more slowly than ecosystem function (e.g., decomposition, productivity). For example, stream litterfall inputs had only recovered to $\sim 50 \%$ following Hurricane Hugo after five years and fine-root biomass had not recovered from the 1994 drought even after five years. Conversely, our data suggest that decay rates and nutrient-release rates from decomposing tissues are relatively unaffected by disturbance events and are a buffered part of the ecosystem. As evidence of the resiliency of the decomposer system and associated release of nutrients, our results show that measures of plant growth, tree BAI and palm frond turnover rates, were relatively insensitive to weather disturbances.

Our research suggests that legacies from hurricanes (i.e., coarse wood transferred to the forest floor), a land use (i.e., planting $\mathrm{N}_{2}$-fixing shade trees for coffee), and plant species-specific chemistry (i.e., as regulators of decomposition rates and not weather) influence the recovery rates of these forests when exposed to additional disturbances. For example, coarse wood decaying on the ground and higher $\mathrm{N}$ levels in the soil resulted in faster growth rates of dominant overstory trees. While research done in other systems has shown limited recovery following disturbance due to legacies (Richter et al. 2000, Markewitz et al. 2004), our research shows that certain legacies in the LEF ecosystem can actually reduce recovery times following weather events. Future research in this ecosystem and others should aim to characterize the attributes of legacies that determine how they will affect an ecosystem's trajectory following disturbance.

We also found that legacy effects varied depending on the structural and functional characteristics of the ecosystem or, in another way, that different types of legacies interacted in ways that changed the manner in which each legacy was expressed. For example, we found that sites that were more productive, potentially as a result of their land use history, had greater resistance to weather events and coarse-wood inputs than less productive sites, probably because the wood served as a smaller relative input of nutrients to the ecosystem. While we are just beginning to appreciate the importance of understanding site legacies in predicting ecosystem responses to disturbance (Foster et al. 2003), our study suggests that we may also need to have a good understanding of the ways in which interactive effects among legacies influence legacy expression.

\section{ACKNOWLEDGMENTS}

This research was supported by National Science Foundation grant \#BSR-8811902 (to the Terrestrial Ecology Division, University of Puerto Rico, and the International Institute of Tropical Forestry, U.S. Forest Service, Puerto Rico, as part of the LTER Program in the LEF) and DEB-9306758 to Yale University and Colorado State University. We thank Sandra Brown and Jennifer Palmiotto for help with the study design. We thank Susan Durham for statistical advice and Andrew Kulmatiski, Debra Peters, and two anonymous reviewers for comments on previous versions of this manuscript. 


\section{Literature Cited}

Anderson, J. M., and J. S. I. Ingram. 1989. Tropical soil biology and fertility: a handbook of methods. C.A.B. International, Wallingford, UK.

Basnet, K., G. E. Likens, F. N. Scatena, and A. E. Lugo. 1992. Hurricane Hugo: damage to a tropical rain forest in Puerto Rico. Journal of Tropical Ecology 8:47-55.

Basnet, K., F. N. Scatena, G. E. Likens, and A. E. Lugo. 1993. Ecological consequences of root grafting in tabonuco (Dacryodes excelsa) trees in the Luquillo Experimental Forest, Puerto Rico. Biotropica 2:28-35.

Berni, C. A., E. Bolza, and F. J. Christensen. 1979. South American timbers: the properties, uses and characteristics of 190 species. Commonwealth Scientific and Industrial Research Organization, Melbourne, Victoria, Australia.

Bloomfield, J. 1993. Nutrient dynamics and the influence of substrate quality on the decomposition of leaves and fine roots of selected tree species in a lower montane tropical rain forest in Puerto Rico. Dissertation. Yale University, New Haven, Connecticut, USA.

Bloomfield, J., K. A. Vogt, and D. J. Vogt. 1993. Decay rate and substrate quality of fine roots and foliage of two tropical tree species in the Luquillo Experimental Forest, Puerto Rico. Plant and Soil 150:233-245.

Bloomfield, J., K. A. Vogt, and P. Wargo. 1996. Tree root turnover and senescence. Pages 363-381 in Y. Waisel, A. Eshel, and U. Kafkafi, editors. Plant roots: the hidden half. Marcel Dekker, New York, New York, USA.

Boccheciamp, R. A. 1977. Soil survey of Humacao area of eastern Puerto Rico. USDA Soil Conservation Service, San Juan, Puerto Rico.

Boose, E. R., D. R. Foster, and M. Fluet. 1994. Hurricane impacts to tropical and temperate forest landscapes. Ecological Monographs 64:369-400.

Bowden, R. D., M. S. Castro, J. M. Melillo, P. A. Steudler, and J. D. Aber. 1993. Fluxes of greenhouse gas between soils and the atmosphere in a temperate forest following a simulated hurricane blowdown. Biogeochemistry 21:6171.

Brown, S., and A. E. Lugo. 1982. The storage and production of organic matter in tropical forests and their role in the global carbon cycle. Biotropica 14:161-187.

Chazdon, R. L. 2003. Tropical forest recovery: legacies of human impact and natural disturbances. Perspectives in Plant Ecology, Evolution and Systematics 6:51-71.

Chinea, J. D., and E. H. Helmer. 2003. Diversity and composition of tropical secondary forests recovering from large-scale clearing: results from the 1990 inventory in Puerto Rico. Forest Ecology and Management 180:227240.

Covich, A. P., T. A. Crowl, and F. N. Scatena. 2003. Effects of extreme low flows on freshwater shrimps in a perennial tropical stream. Freshwater Biology 48:1199-1206.

DeAngelis, D. L. 1980. Energy flow, nutrient cycling, and ecosystem resilience. Ecology 61:764-771.

Ewel, J. J., and J. L. Whitmore. 1973. The ecological life zones of Puerto Rico and the U.S. Virgin Islands. Forest Service Research Paper ITF-18. U.S. Forest Service, Institute of Tropical Forestry, Rio Piedras, Puerto Rico.

Foster, D. R., M. Fluet, and E. R. Boose. 1999. Human or natural disturbance: landscape-scale dynamics of the tropical forests of Puerto Rico. Ecological Applications 9:555572.

Foster, D., F. Swanson, J. Aber, I. Burke, N. Brokaw, D. Tilman, and A. Knapp. 2003. The importance of land-use legacies to ecology and conservation. BioScience 53:7788.

Frangi, J. L. 1998. A flood plain palm forest in the Luquillo Mountains of Puerto Rico five years after Hurricane Hugo. Biotropica 30:339-348.
Garcia-Martino, A. R., G. S. Warner, F. N. Scatena, and D. L. Civco. 1996. Rainfall, runoff and elevation relationships in the Luquillo Mountains of Puerto Rico. Caribbean Journal of Science 32:413-424.

Garcia-Montiel, D. C., and F. N. Scatena. 1994. The effect of human activity on the structure and composition of a tropical forest in Puerto Rico. Forest Ecology and Management 63:57-78.

Goering, H. K., and P. J. van Soest. 1970. Forage fiber analysis: apparatus, reagents, procedures, and some applications. Agricultural Handbook 379. Agricultural Research Service, United States Department of Agriculture, Washington, D.C., USA.

Harmon, M. E., D. F. Whigham, J. Sexton, and I. Olmstead. 1995. Decomposition and mass of woody detritus in the dry tropical forests of the northeastern Yucatan Peninsula, Mexico. Biotropica 27:305-316.

Humphries, P., and D. S. Baldwin. 2003. Drought and aquatic ecosystems: an introduction. Freshwater Biology 48:11411146.

Kavanagh, T., and M. Kellman. 1992. Seasonal pattern of fine root proliferation in a tropical dry forest. Biotropica 24:157-165.

Larsen, M. C. 2000. Analysis of 20th century rainfall and streamflow to characterize drought and water resources in Puerto Rico. Physical Geography 21:494-521.

Lodge, D. J., F. N. Scatena, C. E. Asbury, and M. J. Sanchez. 1991. Fine litterfall and related nutrient inputs resulting from hurricane Hugo in subtropical wet and lower montane rain forests of Puerto Rico. Biotropica 23:336-342.

Lugo, A. E., and F. N. Scatena. 1995. Ecosystem-level properties of the Luquillo Experimental Forest with emphasis on the Tabonuco Forest. Pages 59-108 in A. E. Lugo and C. Lowe, editors. Tropical forests: management and ecology. Ecological Studies 112. Springer-Verlag, New York, New York, USA.

Lugo, A. E., and F. N. Scatena. 1996. Background and catastrophic tree mortality in tropical moist, wet, and rain forests. Biotropica 28:585-599.

Lugo, A. E., and R. B. Waide. 1993. Catastrophic and background disturbance of tropical ecosystems at the Luquillo Experimental Forest. Journal of Bioscience 18:475-481.

Markewitz, D., E. Davidson, P. Moutinho, and D. Nepstad. 2004. Nutrient loss and redistribution after forest clearing on a highly weathered soil in Amazonia. Ecological Applications 14:S177-S199.

McCormick, J. F. 1996. A review of the population dynamics of selected tree species in the Luquillo Experimental Forest, Puerto Rico. Pages 224-257 in A. E. Lugo and C. Lowe, editors. Tropical forests: management and ecology. Ecological Studies 112. Springer-Verlag, New York, New York, USA.

Nadelhoffer, K. J. 2000. The potential effects of nitrogen deposition on fine-root production in forest ecosystems. New Phytologist 147:131-139.

Ostertag, R., F. N. Scatena, and W. Silver. 2003. Forest floor decomposition following hurricane litter inputs in several Puerto Rican forests. Ecosystems 6:261-273.

Richter, D. D., D. Markewitz, P. R. Heine, V. Jin, J. Raikes, K. Tian, and C. G. Wells. 2000. Legacies of agriculture and forest regrowth in the nitrogen of old-field soils. Forest Ecology and Management 138:233-248.

Sanford, R. L., W. J. Parton, D. S. Ojima, and D. J. Lodge. 1991. Hurricane effects on soil organic matter dynamics and forest production in the Luquillo Experimental Forest, Puerto Rico: results of simulation modeling. Biotropica 23: 364-372.

Scatena, F. N. 1989. An introduction to the physiography and history of the Bisley experimental watersheds in the Luquillo Mountains of Puerto Rico. General Technical Report 
SO-72. U.S. Derpartment of Agriculture, New Orleans, Louisiana, USA.

Scatena, F. N. 1995. Relative scales of time and effectiveness of watershed processes in a tropical montane rain forest of Puerto Rico. Geophysical Monograph 89:103-111.

Scatena, F. N., and M. C. Larsen. 1991. Physical aspects of Hurricane Hugo in Puerto Rico. Biotropica 23(4a):317323.

Scatena, F. N., and A. E. Lugo. 1995. Geomorphology, disturbance, and the soil and vegetation of two subtropical wet steepland watersheds in Puerto Rico. Geomorphology 13:199-213.

Scatena, F. N., S. Moya, C. Estrada, and J. D. Chinea. 1996. The first five years in the reorganization of aboveground biomass and nutrient use following Hurricane Hugo in the Bisley experimental watersheds, Luquillo Experimental Forest, Puerto Rico. Biotropica 28:424-440.

Scatena, F. N., W. Silver, T. G. Siccama, A. H. Johnson, and M. J. Sanchez. 1993. Biomass and nutrient content of the Bisley experimental watersheds, Luquillo Experimental Forest, Puerto Rico, before and after Hurricane Hugo, 1989. Biotropica 25:15-27.

Schowalter, T. D., and L. M. Ganio. 1999. Invertebrate communities in a tropical rain forest canopy in Puerto Rico following Hurricane Hugo. Ecological Entomology 24: 191-201.

Shaw, W. B. 1983. Tropical cyclones: determinants of pattern and structure in New Zealand's indigenous forests. Pacific Science 37:405-414.

Silver, W. L., F. N. Scatena, A. H. Johnson, T. G. Siccama, and F. Watt. 1996. At what temporal scales does disturbance affect belowground nutrient pools? Biotropica 28: 441-457.

Silver, W. L., and K. A. Vogt. 1993. Fine root dynamics following single and multiple disturbances in a subtropical wet forest ecosystem. Journal of Ecology 81:729-738.

Thomlinson, J. R., M. I. Serrano, T. D. Lopez, T. M. Aide, and J. K. Zimmerman. 1996. Land-use dynamics in a postagricultural Puerto Rican landscape (1936-1988). Biotropica 28:525-536.

Thompson, J., N. Brokaw, J. K. Zimmerman, R. B. Waide, E. M. Everham, D. J. Lodge, C. M. Taylor, D. GarciaMontiel, and M. Fluet. 2002. Land use history, environment, and tree composition in a tropical forest. Ecological Applications 12:1344-1363.
Vogel, J. L. 1994. Hydrology. Commission on Environment and Technology Systems, National Academy of Sciences, Washington, D.C., USA.

Vogt, K. A., J. C. Gordon, J. P. Wargo, D. J. Vogt, H. Asbjornsen, P. A. Palmiotto, H. J. Clark, J. L. O'Hara, W. S. Keeton, T. Patel-Weynand, and E. Witten. 1997. Ecosystems: balancing science with management. Springer-Verlag, New York, New York, USA.

Vogt, K. A., D. J. Vogt, H. Asbjorsen, and R. A. Dahlgren. 1995. Roots, nutrients and their relationship to spatial patterns. Plant and Soil 168-169:113-123.

Vogt, K. A., D. J. Vogt, P. Boon, A. Covich, F. N. Scatena, H. Asbjornsen, J. L. O'Hara, T. G. Siccama, J. Bloomfield, and J. F. Ranciato. 1996. Litter dynamics along stream, riparian, and upslope areas following Hurricane Hugo, Luquillo Experimental Forest, Puerto Rico. Biotropica 28: $458-470$

Wadsworth, F. H. 1951. Forest structure and productivity in Puerto Rico's Luquillo Mountains. Biotropica 22:69-82.

Walker, L. R. 1995. Timing of post-hurricane tree mortality in Puerto Rico. Journal of Tropical Ecology 11:315-320.

Walker, L. R., J. K. Zimmerman, D. J. Lodge, and S. GuzmanGrajales. 1996. An altitudinal comparison of growth and species composition in hurricane-damaged forests in Puerto Rico. Journal of Ecology 84:877-889.

Wilson, S. D., and D. Tilman. 1991. Components of plant competition along an experimental gradient of nitrogen availability. Ecology 72:1050-1065.

Zimmerman, J. K., E. M. I. Everham, R. B. Waide, D. J. Lodge, C. M. Taylor, and N. V. L. Brokaw. 1994. Response of tree species to hurricane winds in subtropical wet forests in Puerto Rico: implications for tree life histories. Journal of Ecology 82:911-922.

Zimmerman, J. K., W. M. Pulliam, D. J. Lodge, V. QuinonesOrfila, N. Fletcher, S. Guzmán-Grajales, J. A. Parrotta, C. E. Asbury, L. R. Walker, and R. B. Waide. 1995. Nitrogen immobilization by decomposing woody debris and the recovery of tropical wet forest from hurricane damage. Oikos 72:314-322.

Zimmerman, J. K. H., and A. P. Covich. 2003. Distribution of juvenile crabs (Epilobocera sinuatifrons) in two Puerto Rican headwater streams: effects of pool morphology and past land-use legacies. Archiv für Hydrobiologie 158:343357.

\section{APPENDIX}

A table summarizing palm (Prestoea montana) data by catchment and treatment is available in ESA's Electronic Data Archive: Ecological Archives M075-013-A1. 